\title{
EL PROCESO CARTOGRÁFICO DE LA REFORMA PARROQUIAL DEL ARZOBISPO LORENZANA: PROPUESTAS PLANIMÉTRICAS DE JOSÉ ANTONIO DE ALZATE Y RECREACIÓN ILUSTRADA DE LA CIUDAD DE MÉXICO (1767-1772)
}

\author{
José María García Redondo \\ Universidad Nacional Autónoma de México ${ }^{1}$
}

Fl 3 de marzo de 1772, el arzobispo de México, Francisco Antonio de Lorenzana y Butrón, para entonces electo a la sede de Toledo, promulgó el edicto mediante el cual se formalizaba la nueva división y asignación de territorios a las parroquias de la capital del virreinato. ${ }^{2}$ Llegado a México en 1766, en una coyuntura reformista y con el empeño de renovar la Iglesia novohispana en distintos frentes, en apenas unos meses, el prelado -conocido regalista- ya obraba en la reorganización religiosa

Fecha de recepción: 16 de julio de 2017

Fecha de aceptación: 12 de abril de 2018

\footnotetext{
${ }_{1}^{1}$ Programa de Becas Posdoctorales en la UnAm, becario del Instituto de Investigaciones Históricas, asesorado por la doctora Patricia Osante y Carrera y el doctor Felipe Castro Gutiérrez. Trabajo elaborado en el marco del proyecto de investigación "El coleccionismo científico y las representaciones museográficas de la naturaleza y de la humanidad”, HAR2016-75331-P (AEI/ FEDER-UE).

2 Edicto del arzobispo Lorenzana señalando los límites de los curatos y vicarías de la ciudad, 3 de marzo de 1772 . AGN, $B, 587$, vol. 8, n. 78 .
} 
de la urbe. ${ }^{3}$ Para este proyecto contó con la pericia y el ingenio del bachiller José Antonio de Alzate y Ramírez, sacerdote inclinado a las ciencias y a las letras, exponente indiscutido de la Ilustración mexicana. ${ }^{4}$ Como resultado de la colaboración entre ambas personalidades se culminó una prolongada transformación de la traza espiritual de la ciudad de México, lo que suponía una respuesta de carácter "espacial" a una amalgama de circunstancias de orden social, político y religioso: la policía de los indios, la secularización de los curatos y el "principio de separación” que pervivía en las adscripciones parroquiales de españoles y naturales. ${ }^{5}$ Tal y como Roberto Moreno de los Arcos refirió, en una primera síntesis de un gran trabajo que tristemente dejó inacabado, la labor de Lorenzana y Alzate representó "el fin de la ciudad colonial regida por el principio de la separación racial” y apuntaló la "ruptura con las formas que habían permanecido subterráneas de la ciudad antigua". 6

El 23 de enero de 1769, Alzate presentó un proyecto de reorganización parroquial que fue inmediatamente aprobado por el arzobispo y sancionado por el monarca el 12 de marzo de 1771 (mapa 4). No obstante, las reticencias del clero capitalino y el criterio personal de Lorenzana enmendaron a posteriori dicho plan, que devino -con interesantes modificaciones- en la traza

\footnotetext{
${ }^{3}$ Entre otras medidas, no exentas de controversia y conflicto, bajo el gobierno de Lorenzana, se celebró el IV Concilio Provincial Mexicano, se expulsó a la Compañía de Jesús, se impulsó la secularización de los curatos, se procuró la disciplina de monjas y conventos, así como la de las prácticas devocionales del pueblo; Escamilla, "El arzobispo". Hasta la fecha, solo se ha publicado el primer volumen de la biografía de Lorenzana preparada por Luis Sierra Nava-Lasa, El cardenal, que concluye con su partida de México. Sus políticas eclesiásticas han sido analizadas por Zahino PeÑafort, Iglesia.

${ }^{4}$ La vida y la obra de José Antonio de Alzate han sido abordadas en numerosos trabajos. Con una visión de conjunto destacan Moreno, Un eclesiástico, y Saladino, El sabio.

${ }^{5}$ Sobre el “principio de separación”, véase O’Gorman, “Reflexiones”, p. 19.

${ }^{6}$ Moreno, "Los territorios", p. 14.
} 
que se estableció en marzo de 1772. Reproduciendo esta última disposición, el primero de septiembre de 1772, José Antonio de Alzate firmó el "Plano de la Ymperial México, con la nueva distribución de los territorios parrochiales, para la más fácil y pronta administración de los santos sacramentos", el cual entregó "para uso" de Melchor de Peramás, secretario de gobierno del virrey Bucareli (mapa 1). ${ }^{7}$ En él se demarcan en distintos colores las 13 parroquias y tres vicarías, correspondientes a la parroquia del Sagrario, que resultaron de dicha división. Este mapa, conservado en el Museo Franz Mayer en la ciudad de México, es el único ejemplar conocido de los diversos planos generales que se realizaron bajo el patrocinio del arzobispo. Como sugiere la leyenda inscrita, en él se retoma una planta de la ciudad dispuesta por Alzate en 1769 "de orden" de Lorenzana, esto es, un modelo a partir del cual se levantaron diferentes planos con sucesivos ensayos de la reforma parroquial.

Tal y como ha explicado Marcela Dávalos, el "Plano de la Ymperial México" condensa varias miradas cartográficas sobre la ciudad. Aunque Alzate especifica que sigue una escala de 200 varas castellanas, la proporción geométrica no es homogénea en todo el diseño. Mientras que el centro de la urbe se ha construido de manera regular, incluso rectificando y potenciando la rectitud de sus calles, la disposición de los barrios se ha achatado

\footnotetext{
7 "Plano de la Ymperial México, con la nueva distribución de los Territorios Parrochiales, para la más fácil, y pronta administración de los Santos Sacramentos: Dispúsolo en 1769 años de Orden del Ilustrísimo Señor Don Francisco Antonio Lorenzana Buytron, dignísimo arzobispo de esta Santa Iglesia Metropolitana, Don Joseph Antonio Alzate y Ramírez." "Para el uso del Señor don Melchor de Peramás, Secretario de Govierno del Excelentísimo Señor virrey, entregóselo el autor el 1o de septiembre de 1772 años. Joseph Antonio de Alzate y Ramírez." Museo Franz Mayer, inv. 994, cat. AMA-0001. El plano tiene unas dimensiones de $116 \times 144 \mathrm{~cm}$. Agradezco al Museo Franz Mayer las facilidades prestadas para esta investigación. Véase una reseña del plano en LOMBARDo, Atlas, pp. 56-57. Un estudio del plano, especialmente de los barrios, es presentado por Dávalos, Los letrados, pp. 57-73.
} 


\section{Mapa 1}

“PLANO DE LA YMPERIAL MÉXICO” DE JOSÉ ANTONIO

DE ALZATE (1772)

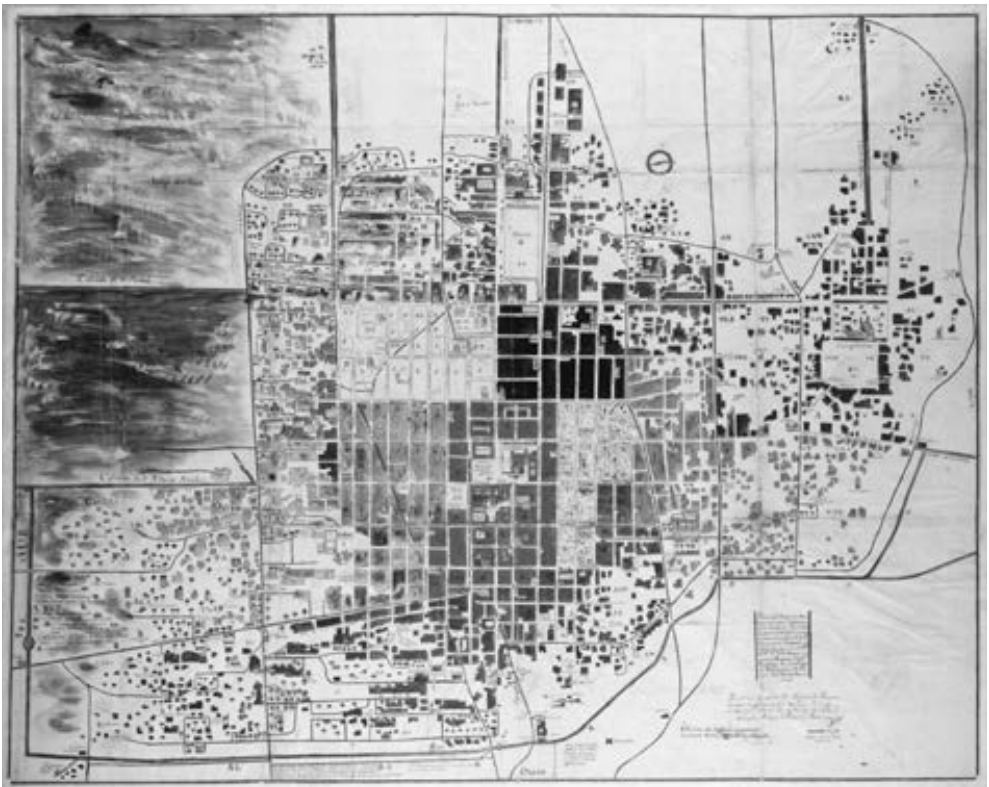

y comprimido en los márgenes. ${ }^{8}$ La sobredimensionada regularidad de la cuadrícula -símbolo de la grandeza de la ciudadfue una atribución frecuente en los mapas y descripciones: "se miran vistosamente repartidas sus calles, que cruzan con la mayor igualdad y rectitud de oriente a poniente y de norte a sur, formando las encrucijadas ángulos perfectos". ${ }^{9}$ Frente a ésta se opondrá la dispersión y el desorden de la periferia, dominada por las aguas, que Alzate no dudará en simplificar:

8 Dávalos, Los letrados, pp. 59-61.

9 Ajorrín, Diario, p. 64. 
En los curatos de Santa Cruz Acatlán y de Santo Thomas hay una gran cantidad de casas de caña que llaman xacales que no se ha especificado en el mapa por ser inaveriguable su situación, abundan principalmente al rumbo del sur de ambos curatos. También es de notar que no se han puesto todas las casillas de adobe de los barrios porque al paso que unas se destruyen otras se reedifican. ${ }^{10}$

Con la construcción ortogonal del plano convive la representación en alzado de los principales edificios de la ciudad, algunos detalles figurativos, como árboles o pequeñas elevaciones, así como hitos urbanos, como cruceros, compuertas y fuentes. Ciertamente, el fin del mapa no era expresar distancias ni proporciones, sino servir como una representación clara y concisa del nuevo orden parroquial, proyectando hacia el futuro la deseada imagen de la ciudad. ${ }^{11}$ Siguiendo la costumbre de otros planos antecedentes, la planta orienta su norte hacia la derecha, ubicando el poniente en la parte superior del dibujo. ${ }^{12}$

En este artículo se explica cómo, antes de la definitiva distribución de 1772 que ilumina el referido "Plano de la Ymperial México”, José Antonio de Alzate realizó diversas versiones cartográficas de la organización parroquial, manteniendo un diseño original que sirvió de plantilla o soporte para aquellos otros mapas con distintas propuestas que fueron objeto de revisión y debate. En este sentido, la hechura de este plano por una mano distinta a la de Alzate -quien tan solo lo dedica y lo firma- revelaría un proceso de estandarización y copia de una imagen concreta de la ciudad, idónea para la discusión de

\footnotetext{
10 Nota en el "Plano de la Ymperial México".

${ }_{11}$ Mundy, “The Images", p. 62.

12 Mundy, “The Images”, pp. 67-68, sugiere que este mapa y el del ingeniero Nicolás Lafora, "Plano de la Imperial corte de México", de 1770, pudieron construirse basándose en un mismo plano. Véase una reproducción del diseño de Lafora, conservado en el Museo Nacional de Historia de México, en LomBARDO, Atlas, pp. 326-327.
} 
las circunscripciones eclesiásticas. Desde 1767 hasta 1772, la reflexión sobre la traza urbana, los barrios y sus moradores, la discusión y la aprobación real de la reasignación territorial en 1771, y su posterior rectificación por decisión de Lorenzana se efectuaron sobre distintos planos donde intervino José Antonio de Alzate. ${ }^{13}$ A partir del análisis de aquellos materiales planimétricos, tanto los estrictamente visuales como los proyectos descritos en las fuentes narrativas, en este trabajo abordo el "proceso cartográfico" en el que transcurrió la renovación de las demarcaciones religiosas de México. La construcción de la imagen definitiva de la traza de la ciudad no ha de entenderse como parte de un esquema lineal y progresivo, sino como una acumulación heterogénea de interpretaciones -realizadas en diferentes espacios y momentos, con distinta autoridad y con disímil repercusión-que no necesariamente convergieron en el resultado final, tal y como muestra el análisis de las fuentes.

Desde que Roberto Moreno de los Arcos analizase los cambios en las circunscripciones parroquiales de la ciudad, en las últimas décadas, diversos autores han tratado la reforma de Lorenzana siguiendo, en esencia, el breve esquema esbozado en el citado estudio. Algunos trabajos, sin reparar en los cambios y reacomodos territoriales planteados entre 1767 y 1772, han considerado la reforma parroquial como un proceso homogéneo y unitario, o bien han expuesto sus distintas etapas y factores de forma muy somera y confusa. En esta línea, no solo se han desatendido cuáles fueron los diversos espacios que mudaron su circunscripción o los argumentos territoriales y cartográficos esgrimidos por unas partes y otras, sino que también se ha atribuido reiteradamente a Alzate una completa autoría sobre el

${ }^{13}$ Una primera y sugerente discusión sobre la interpretación de los barrios de indios realizada por Alzate en sus planos y sus escritos la presentó DÁvalos, Los letrados, pp. 53-77; no obstante, quedaron fuera de su análisis la datación del mapa y la correlación de sus contenidos con las sucesivas fases de la reforma. 
nuevo plan, sin tener en cuenta la renegociación abierta por el arzobispo poco antes de su partida a la metrópoli. En este artículo se estudia la reforma parroquial desde una perspectiva "espacial”, focalizando las sucesivas fases de reordenamiento territorial y los conflictos subyacentes, cuestiones que, cuando han sido abordadas, se han planteado de manera muy tangencial o centradas en casos muy puntuales. ${ }^{14}$ Consecuentemente, al considerar aquí los borradores de Alzate y sus diseños desaparecidos, se fija el contexto de producción de los planos -frecuentemente empleados como meras ilustraciones-, como el referido diseño de 1772 (mapa 1), cuyo contenido y data han sido confundidos como propios de 1769. Por otro lado, atendiendo al horizonte ilustrado -no exento de contradicciones y de rémoras- donde se idearon las reformas, se profundiza en las discusiones acerca de las modificaciones del espacio eclesiástico, entendiendo éstas como un primer nivel de acción posible dentro de un difuso e improvisado programa de transformación total de la ciudad.

\section{LOS CURATOS DE MÉXICO: UN VIEJO PROBLEMA ESPACIAL}

Desde el siglo xvi, los curatos de la ciudad de México se habían organizado manteniendo la segregación étnica impuesta tras la conquista. Sin embargo, el aumento de la población y la dispersión espacial de indios y españoles -incluyendo negros, mestizos y castas- devino en la superposición espacial de las adscripciones parroquiales. ${ }^{15} \mathrm{El}$ mapa parroquial era verdaderamente confuso

14 Este es el caso, por ejemplo, del reciente y minucioso trabajo de O'Hara, A Flock, donde el autor se centra más en las prácticas devocionales y los conflictos entre los feligreses y el clero, a consecuencia de la reforma, que en la cuestión territorial.

15 Zahino, Iglesia, pp. 50-53; Moreno de los Arcos, "Los territorios", pp. 4-15; SÁnchez SANTIRó, “El nuevo orden”, pp. 64-75. LiRA, Comunidades, pp. 28-39. Sobre la organización simbólica de la ciudad, véase, además, Romero, "La ciudad”, pp. 28-32. 
y problemático, pues se trataba de "una división sectorial-étnica, más que territorial” ${ }^{16}$ Unida al traslape de las jurisdicciones, la indeterminación étnica de ciertos fieles fue motivo de conflictos entre los propios párrocos y de éstos con su feligresía. Frecuentemente, la identidad de indios y mestizos se rebatía o reconstruía ante determinadas situaciones, como el control del precepto anual, la administración de los sacramentos o su inscripción en los padrones. ${ }^{17}$ Así lo manifestó en 1770 el recién nombrado cura secular de la parroquia de indios de San Pablo, quien observó cómo algunos de sus feligreses "inconcusamente indios" estaban empadronados en la de San Miguel, reservada a los españoles; al igual que otros "muchos asimismo indios que viven en la misma plazuela de San Pablo y en sus cercanías han sido empadronados por el padre cura de la parroquia del Señor San Josef, quien constantemente alega jurisdicción en muchos de los indios vecinos de esta parroquia de que tengo repetidos documentos" ${ }^{18}$ En la práctica, además de la separación por calidades, se agregaba "otra nueva confusión y dificultad": la adscripción de los naturales según sus oficios. Así, el referido párroco se quejó de encontrar "en los padrones maladas [sic] las panaderías de la calle de San Ramón, del puente de Jesús y de la calle del Rastro", y criticó cómo la parroquia de San José "tiene por suios a los que son de oficio carniceros", lo que provocaba "fraudes para los padrones". ${ }^{19}$

\footnotetext{
16 SiERra, El cardenal, p. 137.

17 Zahino, Iglesia, p. 52; O’Hara, A Flock, pp. 40-54.

18 Carta de Juan Joseph Pina, párroco de San Pablo, al arzobispo Lorenzana, 5 de marzo de 1770. AGN, TC, vol. 8, exp. 4, f. 106r. Sierra, El cardenal, p. 139. 19 Carta de Pina a Lorenzana, 10 de mayo de 1770. AGN, TC, vol. 8, exp. 4, f. 107r.-v. Para mayor confusión, los dominicos mantuvieron hasta los años cincuenta del siglo XVIII una parroquia no territorial para atender a los indios mixtecos, zapotecos, criollos, extravagantes y de Meztitlán. Castro, “El origen”, p. 112; O’Hara, A Flock, pp. 41-42; Pescador, De bautizados, pp. 28-29.
} 
En 1766, cuando Lorenzana tomó posesión de la sede novohispana, la capital mantenía desde finales de la centuria anterior una compleja división en diez curatos (mapa 2). ${ }^{20}$ Cuatro eran parroquias de españoles y estaban administradas por el clero secular: el Sagrario, San Miguel, Santa Catarina Mártir y Santa Veracruz. Sobrepuestos en el territorio, los otros seis curatos estaban reservados a la población india y, tradicionalmente, a la labor de las órdenes religiosas: San José y Santiago Tlatelolco estaban a cargo de los franciscanos, San Pablo, de los agustinos, mientras que Santa Cruz Coltzingo, San Sebastián Atzacoalco y Santa María la Redonda acababan de pasar a manos de los sacerdotes seculares bajo la prelacía de Manuel Rubio y Salinas (1749-1765). ${ }^{21}$ No obstante, lejos de ser firmes, los ámbitos de cada colación se prestaban a discusión. Difícilmente los párrocos podían alegar algún mapa o "instrumento en que consten los límites de su curato". ${ }^{22}$ En este sentido, cuando San Pablo pasase a los seculares, su cura lamentaría cómo, "no haviendome entregado ni hallado en el archivo de esta parroquia documento de donde consten sus límites para poder formarme alguna idea, me he valido del arbitrio de reconocer con toda exactitud los que ofrecen los padrones que me entregaron los religiosos". ${ }^{23}$

En el Siglo de las Luces, aquella división étnica suponía un obstáculo a la integración de ambas repúblicas en un renovado orden urbano que lograría la armonización de la sociedad mexicana en el conjunto de la monarquía. La preeminencia de

\footnotetext{
20 Moreno de los Arcos, “Los territorios”; Rubial, “¿El final?”.

${ }^{21}$ Las doctrinas de Santa Cruz y San Sebastián dejaron de pertenecer a los agustinos en 1750 y la de Santa María pasó de los franciscanos al clero secular en 1753. Durante el mismo periodo se suprimió la llamada doctrina de indios extravagantes. ÁlvAREz-ICAZA, "La secularización”, pp. 309-312. Sobre la situación de los curatos hacia 1755, VILlaseñor, Theatro, pp. 720-737.

${ }^{22}$ Carta de Lorenzana a Pina, 6 de abril de 1770. AGN, TC, vol. 8, exp. 4, f. $106 \mathrm{v}$.

${ }^{23}$ Carta de Pina a Lorenzana, 10 de mayo de 1770. AGN, TC, vol. 8, exp. 4, ff. 106v.-107r.
} 


\section{Mapa 2}

DIVISIÓN PARROQUIAL DE LA CIUDAD DE MÉXICO HACIA 1766

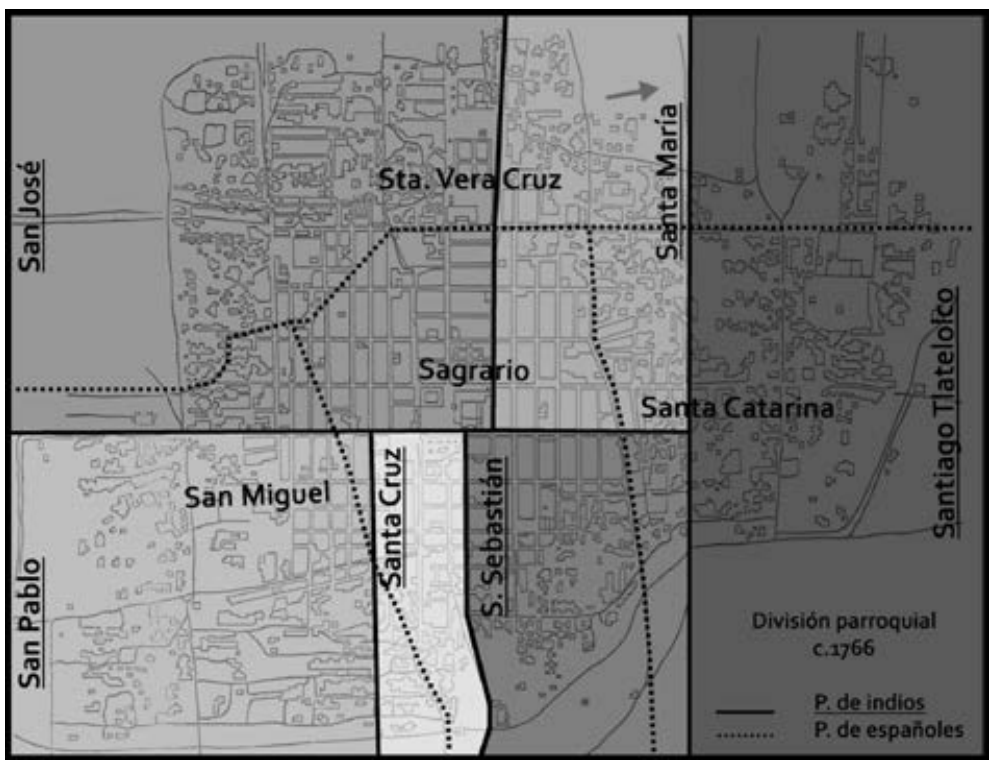

los religiosos en la administración de los curatos no solo perpetuaba este sistema, sino que restaba autoridad y jurisdicción al arzobispo y, por ende, al rey. ${ }^{24}$ Como ha explicado Teresa Álvarez-Icaza, ya desde mediados del siglo xvi, la existencia de parroquias regentadas por frailes era percibida por las autoridades novohispanas como una situación "transitoria" y "excepcional" a la que habría de seguir su secularización. ${ }^{25}$ Consecuentemente, se acabaría por imponer el criterio de someter el sistema a un orden territorial que, por un lado, privase a los regulares de dichas labores y los redujese a los conventos y a las misiones de frontera y, por otro, permitiese la recuperación

24 Zahino, Iglesia, p. 55.

25 Álvarez-Icaza, La secularización, pp. 36-62. 
de las jurisdicciones eclesiásticas, renovando sus divisiones en ámbitos más manejables y, en suma, racionalizando la estructura eclesiástica de la ciudad. ${ }^{26}$

A mediados del siglo xviII, la corona comprendía al episcopado como un cuerpo de agentes que colaboraría activamente en la consecución de una nueva sociedad ${ }^{27} \mathrm{y}$, para ello, se promovieron clérigos partidarios de una renovación ilustrada, como fue el caso de Lorenzana. ${ }^{28}$ Así, el gran impulso a la exoneración de los religiosos no se dio sino hasta la prelacía de Rubio y Salinas, a quien seguiría, en la misma línea, su sucesor Lorenzana. ${ }^{29}$ En el caso de la ciudad de México, durante su gobierno, pasaron al clero diocesano los tres curatos que quedaban en manos de los religiosos: San Pablo en 1767, San José en 1770 y Santiago en 1771. Para finales de la década de 1780 , la mayoría de las parroquias de la arquidiócesis de México habían sido secularizadas. ${ }^{30}$ Respecto a la reforma territorial de los curatos, cuando Carlos III promulgó el llamado Tomo Regio, no se dudó en demandar explícitamente la organización racional de sus jurisdicciones:

Que se dividan las parroquias donde su distancia o número lo pida para la mejor asistencia y administración de sacramentos de los fieles, arreglando el Concilio los medios de ejecutar esto, con intervención del vicepatrono, y sin perjuicio del Patronato Real, ni del erario, prefiriendo en esta división y cómoda distribución de parroquianos, el bien espiritual de éstos, al interés bursático de los

${ }^{26}$ LiRA, “Divisiones”, pp. 38-39; García, “Re-formar”, p. 257.

27 Véase, por ejemplo, Revillagigedo, "Oficio". Sobre la deseada colaboración entre el episcopado y los virreyes, Álvarez-IcAzA, La secularización, p. 90; Aguirre, “La secularización”, p. 499.

${ }_{28}$ TAYlor, Ministros, pp. 27-40; Escamilla, "La Iglesia”.

29 Álvarez-Icaza, La secularización, pp. 86-149; Ấlvarez-IcAzA, "La reorganización”.

30 Zahino, Iglesia, pp. 114-118; Sierra, El cardenal, pp. 169-193; ÁlvarezIcAZA, "La secularización”, pp. 303-325. 
actuales párrocos, y entretanto que esto se formalice, los obliguen los diocesanos a dotar y poner teniente. ${ }^{31}$

LAS BASES DE LA REFORMA: TANTEOS INICIALES (1767-1768)

Aunque el Tomo Regio otorgó el respaldo suficiente a la deseada reforma parroquial de México, para entonces, el arzobispo Lorenzana ya se afanaba en su transformación de la ciudad. Los primeros pasos datan de abril de 1767, cuando Lorenzana, con el pretexto de abordar la secularización de los curatos, manifestó al rey sus intenciones: dada la "gran confusión" imperante en la parroquia de San José, "por comprehender mucha parte de la ciudad, atravesando por el distrito otras parroquias [y] llegando su demarcación a bastantes pueblos de las cercanías", sería oportuno que, "si se señalara territorio a cada uno de los quatro curas del sagrario, secularizase, y dividiera en más parroquias la citada de San Joseph, podrían los pastores conocer sus ovejas que no podían en la actualidad ni informarse de sus necesidades". ${ }^{32}$

Para reordenar el territorio parroquial, explica Marcela Dávalos, el arzobispo requirió una "representación cabal del espacio urbano". ${ }^{33}$ Ante sus ojos, un joven José Antonio de Alzate se postuló como el perfil idóneo al que podía confiar su proyecto. Sin haber cumplido los 30 años de edad, Alzate había demostrado ser un gran conocedor de la ciudad y tener capacidad suficiente

31 Real cédula de Carlos III a los arzobispos de Nueva España y de Filipinas, conocida como Tomo Regio, San Ildefonso, 21 de agosto de 1769. Nuevo Código de Leyes de Indias, Libro I, Título 6 " "De los concilios provinciales y sinodales", Recopilación octava, Ley 1, "Para la convocatoria y celebración de Concilios provinciales se observe el Tomo Regio", en Navarro, Homenaje, pp. 171-174. Texto reproducido también en ZAHINO, El Cardenal, pp. 49-53. Un minucioso análisis sobre el Tomo Regio lo ofrece Hera, "El regalismo", pp. 13-20. Para una visión de conjunto, véase Rubial, La Iglesia, pp. 403-532.

32 Informe de la contaduría general, Madrid, 19 de enero de 1770. AGI, $M$, 727, f. 1 r.-v.

33 Dávalos, Los letrados, p. 57. 
como para plantear soluciones a sus problemas y expresarlas visualmente en un soporte cartográfico. ${ }^{34}$ En 1767, había presentado al ayuntamiento de la ciudad un proyecto con sus diseños para desaguar la laguna de Texcoco ${ }^{35}$ y también había dedicado al arzobispo un mapa "de toda la América septentrional”, "estimulado del propio espíritu, y reconociendo no encontrarse [otro] que se aproximase en algo a la realidad". ${ }^{36}$ De esta forma, en aquel mismo año, Alzate, sacerdote diocesano y sin parroquia a su cargo, empezó a trabajar al servicio de Lorenzana en su reforma de la ciudad. ${ }^{37}$ Aunque es probable que el arzobispo contase con el consejo de otras personalidades, a lo largo de su vida, el bachiller reivindicó como propia la hechura de la traza parroquial, reiterando su labor discreta y en solitario. Con orgullo, dos décadas más tarde, no dudó en exagerar que fue su plan el definitivamente implantado "y contra el que hasta el día no se ha ofrecido disputa alguna”, omitiendo las quejas de los curas y las modificaciones impuestas por Lorenzana tras la sanción real. ${ }^{38}$

34 DÁvalos, Los letrados, pp. 57-79, agrega el conocimiento y compenetración de Alzate con los grupos indígenas residentes en la ciudad, conectando su labor al frente del proyecto parroquial con las consideraciones que posteriormente escribiría sobre los indios. En este mismo sentido, es de destacar el "Plano de Tenochtitlan, Corte de los emperadores mexicanos” realizado por Alzate hacia 1789, donde recogió las antiguas denominaciones indígenas de la ciudad. BNF, $M M, 150$. Véase al respecto, Mundy, “Place-Names”, pp. 339-347, donde lo pone en relación con el referido "Plano de la Ymperial México".

35 José Antonio de Alzate, "Proyecto para desaguar la laguna de Tezcoco y por consiguiente las de Chalco y San Cristóbal”, 1767. AGN, D, vol. 17, exp. 10. 36 "Memorias, servicios y obras escritas y publicadas y comisiones particulares del presbítero don José Antonio de Alzate Ramírez, residente en México, 1790”, AGI, M, 1883, f. 1r. Transcrito por Moreno de los Arcos en Alzate, Memorias, pp. 141-142. Se refiere al "Nuevo Mapa Geographico de la America Septentrional Española” de 1767, MN, 7-A-8.

37 Alzate, Memorias, p. 31; Moreno de los Arcos, Un eclesiástico, p. 26. Véanse sus aspectos familiares y económicos en Moreno DE LOS Arcos, "La familia”.

38 Representación de Alzate al virrey segundo conde de Revillagigedo, 14 de marzo de 1791. AGN, $H$, vol. 74, exp. 1, f. 16v. 
La confusión que se padecía en esta capital, por lo perteneciente a los territorios parroquiales, movió el citado año de 69 al eminentísimo prelado hoy de Toledo, y entonces de México, a procurar un nuevo arreglo, para el cual se valió de mi insuficiencia y con lo arduo de sacar el plano de la ciudad por las noches para que nada percibiese el público, dispuse la distribución que se halla establecida, y fue aprobada por el supremo consejo. ${ }^{39}$

Alzate recibió la orden de "disponer en un plano en que estén bien proporcionados los territorios parrochiales de esta capital de México” y así, entre 1767 y 1768, consideró las primeras medidas para atajar el desorden parroquial. ${ }^{40}$ De esta forma, precediendo al proyecto del 23 de enero de 1769 (mapa 4), el presbítero levantó -al menos- una primera planta de la ciudad donde quedaron recogidos sus tanteos iniciales. La existencia de aquel dibujo la conocemos únicamente por la referencia, en enero de 1769, como "el plano que le hice más ha de un año", ${ }^{41}$ mientras que sus contenidos podemos deducirlos del "Papel sobre el arreglo de parroquias de la ciudad y arrabales de México", documento anónimo y sin fecha del que se guarda una copia inconclusa en la Biblioteca de Castilla-La Mancha, en Toledo. ${ }^{42}$ No obstante, el carácter eclesial de sus valoraciones, la

39 “Memorias, servicios y obras...", AGI, $M$, 1883, f. 2r. Transcrito por Moreno de los Arcos en Alzate, Memorias, p. 143.

40 José Antonio de Alzate, "Memoria del plano con la nueva distribución parroquial de México", 23 de enero de 1769. BCM, $B L, P V$, ms. 26, n. 13, f. 1 r. Tachado en el documento original. Para facilitar su cita, en adelante me refiero a este documento como "Memoria".

${ }_{41}$ Alzate, "Memoria", f. 4v.

42 José Antonio de Alzate, "Papel sobre el arreglo de parroquias de la ciudad y arrabales de México", c. 1768. BCM, $B L, P V$, ms. 26, n. 10. En adelante citado como "Papel". A Toledo fueron a parar los papeles de Lorenzana una vez que tomó posesión como arzobispo primado de España. Por las referencias sobre el estado de las parroquias, la persistencia de los curatos en manos de los regulares y la reciente conclusión de las obras del Sagrario catedralicio, el 
preocupación ilustrada por cuestiones urbanísticas y su visión cosmopolita de los problemas apuntan certeramente al genio y la pluma de José Antonio de Alzate. ${ }^{43}$

Compuesto a la vista de alguno de aquellos primeros planos, el programa de reformas del "Papel" se inscribe dentro de las dinámicas de pensamiento y las prácticas urbanísticas del siglo XVIII español, influenciadas por las tendencias francesas del momento. ${ }^{44}$ La premisa que regía aquel "gran proyecto" era extender y consolidar el "orden y bella colocación que esta [capital] tiene en sus calles". ${ }^{45}$ La racionalización del espacio ciudadano se implementó no solo como una forma de embellecimiento u ornato, sino como una estrategia de ordenación territorial y social cuyo último fin era mantener el dominio sobre los espacios y las personas. ${ }^{46} \mathrm{En}$ tanto que no llegaron a reflejar la representación final de la reforma, ni tampoco se conoce ningún ejemplar, dichos primeros diseños podrían considerarse como un instrumento menor, meros borradores de carácter provisional, en el proceso de planificación. Sin embargo, desde el momento en que se produjeron, tales imágenes constituyeron en sí mismas herramientas autónomas con un decidido papel en la comunicación visual del proyecto, la sustentación teórica de sus objetivos y la persuasión de sus detractores.

Desde hacía unas décadas, la ciudad de México estaba siendo sometida a intervenciones infraestructurales y urbanísticas -iluminadas por las Luces- no exentas de una dimensión

documento debió elaborarse hacia 1768. Mi agradecimiento al personal de la BCM por su ayuda.

${ }^{43}$ Mazín, "Espacio", p. 57, ya atribuyó este documento a Alzate. Desde una perspectiva religiosa, el "Papel" funge como un pormenorizado informe sobre el estado general de las parroquias dirigido al recién llegado arzobispo, su funcionamiento y organización, así como las dificultades sociológicas y económicas de la labor pastoral.

${ }^{44}$ SAmbricio, "El urbanismo", pp. 142-144.

${ }^{45}$ Alzate, "Papel”, f. $1 \mathrm{r}$.

46 Reguera, Territorio, pp. 110-122. 
simbólica orientada a adecuarla como emblema del poder virreinal. ${ }^{47}$ Como explicó Sánchez de Tagle, los ideales ilustrados de higiene y armonía sirvieron para justificar las verdaderas preocupaciones de ostentación de los virreyes, para quienes el boato en la remoción urbana era "la mejor forma conocida de imponer la autoridad". ${ }^{48}$ De igual manera, parafraseando a Henri Lefebvre, Alzate intentó "producir" en sus planos y en su "Papel" una ciudad que reflejase aquel sistema de valores ilustrados, de manera "inmediata (visible y legible sobre el propio terreno), al dar forma a las relaciones sociales más abstractas, jurídicas, políticas e ideológicas". ${ }^{49}$

En la línea de los "proyectistas" de su siglo, con vocación de utilidad pública y de engrandecimiento de la nación, ${ }^{50} \mathrm{Alza}$ te estimó su propuesta de reforma no solo conducente "al beneficio espiritual, sino también para lo civil y político de la república" ${ }^{51}$ En este sentido, manifestó cómo se podrían mejorar las condiciones de vida de los indios de los arrabales. En su opinión, uno de los grandes problemas de la urbe consistía en que, por descuido de la Junta de Policía, se había permitido la construcción de casas en la periferia sin orden ni concierto, lo que dificultaba el socorro espiritual y acarreaba "graves inconvenientes para lo civil y económico". En dichas áreas, los naturales, "que sobreviven como brutos, están metidos en el agua, expuestos y aun precisados a contraer y comunicar enfermedades". ${ }^{2}$ En la interpretación alzatiana rezumaba la clásica oposición "ciudad-campo" que, desde mediados del siglo xviII, políticos y planificadores del crecimiento urbano

\footnotetext{
47 Hernández, “Ideología”, pp. 117-119.

48 SÁnchez de Tagle, "La remodelación”, p. 18.

${ }^{49}$ Lefebvre, La revolución, p. 30.

${ }^{50}$ Sobre el proyectismo, véase el artículo de MuÑoz "Los proyectos”, y para el caso concreto de Nueva España, GutiérREz, "Juan Gassiot”.

51 Alzate, "Papel”, f. 3v.

52 Alzate, "Papel”, ff. 2v.-3r.
} 
manejaron como una categoría analítica que les permitía comprender y explicar la novedad de la "ciudad moderna" como producto del "crecimiento cuantitativo de los asentamientos del pasado" y como resultado de una decidida intervención que fuese más allá de sus propios límites. ${ }^{53}$ Para los letrados de finales de dicha centuria, era absoluta la falta de "unidad" entre el centro y la periferia de México. Las frecuentes propuestas, dirigidas a solventar la suciedad e irregularidad de los barrios suburbanos, se preocuparon "por integrar esas dos ciudades que antaño se dieron la espalda". ${ }^{54}$ No obstante, lejos de una utopía inclusiva, en las valoraciones ilustradas, tan preocupante resultaba la profilaxis de la población hispana como la confusión étnica y el desconcierto urbanístico: era un problema que "el casco de aquella ciudad se llene de indios mezclados con otras castas y multipliquen los pecados, oscurezca su hermosura, haya grandísimo desorden y confusión, y el mal o peste que llaman matlazahuatl se comunique a los españoles con más facilidad". ${ }^{55}$

Mediante el juicio visual de la traza urbana -expresada en soporte cartográfico- lo que se analizaba y pretendía rectificar no era sino la "imagen" de la capital que se tenía a la vista. Alzate advierte, por un lado, cómo "se ha perdido en muchas calles la capacidad y rectitud con que se delineó a los principios” y, por otro, cómo la ciudad, "extendiéndose notablemente por algunas partes, se ha enflaquecido por otras, y perdiendo el cuerpo la perfección que fácilmente pudiera mantener" ${ }^{56}$ La nueva ciudad se sustenta en un espacio ordenado, simétrico y uniforme. ${ }^{57}$ Por tanto, los baldíos y "las fábricas [de las casas] en los parajes que

53 Signorelli, Antropología, pp. 32-34. Sobre las intervenciones ilustradas en la ciudad de México, Sánchez De Tagle, Los dueños.

${ }^{54}$ Fernández, Europa, p. 73; DÁvalos, Los letrados.

${ }^{55}$ Respuesta del fiscal del Consejo de Indias, 31 de mayo de 1769. AGI, $M, 727$.

${ }^{56}$ Alzate, "Papel”, f. 2v.

57 Fernández, Europa, pp. 72-75. 
traen deformidad" 58 se consideran un obstáculo que quiebra la deseada "lógica de la forma" urbana, donde todo es calculable o "programable" y persigue una cierta geometría y aspira -a decir de Lefebvre-a una "legibilidad" o "analogía de la simultaneidad urbana con la escritura, con el orden racional de los elementos existentes" ${ }^{59}$ Para el joven bachiller, al observar un plano o tan solo con la imagen mental de los alrededores de México, tanto el poblamiento desestructurado como el espacio deshabitado "causan fealdad a la planta de México". ${ }^{60}$

Retomando la metáfora "ciudad-cuerpo" (empleada por los planificadores ilustrados que concibieron los movimientos y flujos de ventilación al modo de las venas y arterias), ${ }^{61}$ el artífice del "Papel" comparó la capital con un "cuerpo humano gravemente enfermo" -como haría, años después, Hipólito Villarroel-y se consideró a sí mismo como el médico que, "con la paciencia de algún más tiempo", podría lograr su "perfecta sanidad y consuelo permanente". ${ }^{62}$ Para ello apuntó una serie de medidas concretas, a pesar de su limitada capacidad de intervención en ciertas cuestiones urbanas. Frente al desorden, el edificio de la parroquia se presentó como eje racionalizador de su vecindario correspondiente. Sin llegar a plasmarse en el proyecto de 1769, el "Papel" tanteó dar mayor equilibrio a la parroquia de la Veracruz -en el extremo poniente de la ciudad- desgajándole

58 Alzate, "Papel”, f. $2 \mathrm{v}$.

59 Lefebvre, La revolución, p. 125.

60 Alzate, "Papel”, f. 3r. Con posterioridad, Alzate será el gran defensor de la renovación de la ciudad de México acorde a sus características humanas y ambientales, debatiendo en sus escritos y en la esfera pública cuestiones como el alumbrado, el adoquinado de las calles, etc. SánCHEZ DE TAGLE, "Antonio Alzate”, pp. 163-178.

${ }^{61}$ Los renovadores de las ciudades del siglo xviII adoptaron este concepto de las obras de Alberti y Vitrubio, sobre las que volvieron buscando la armonía y la simetría humana para los edificios y nuevos planeamientos urbanos. SENNET, Carne. Para el caso de México, Dávalos, Basura, pp. 33-51.

${ }^{62}$ Alzate, "Papel”, f. 1r.-v; Villarroel, Enfermedades. 
el espacio comprendido entre el colegio de San Fernando y la fuente de la Tlaxpana, territorio sin "proporción alguna, aunque es numeroso para establecer una parroquia”. Se pretendía adecuar la iglesia cabecera como centro simbólico y territorial de la colación pues, hasta los referidos márgenes, "dista de este extremo cinco u ocho partes más de los límites que tiene por oriente y norte, y del que se la puede poner al sur". ${ }^{63}$

Contra la dispersión poblacional, la parroquia funcionaría como agente que controlase la reagrupación y diese civilidad a sus moradores. Para acabar con el "enjambre de pueblecitos" situados al poniente de Santiago Tlatelolco, "que solo sirven de fomentar a los indios la barbarie y el vicio", Alzate propuso acercar las familias a Santiago u otra vecindad próxima, donde se les proporcionarían tierras de labor y atención espiritual. Por otro lado, haciendo frente a los "antiestéticos" espacios vacíos en el mapa, abogó por una repoblación ordenada con oriundos de otras barriadas. Aquel era el problema de la parroquia de Santa María, la cual, "aunque se le asigne un territorio proporcionado, siempre quedará despoblada por la parte norte y poniente y sin figura correspondiente”. La solución pasaría por suscitar las providencias necesarias "para poblar aquella parte, que lo exige mucho, como próxima que está al casco de la ciudad”, por lo que sugirió reubicar allí los indios que moraban, en condiciones insalubres, entre el paraje de San Antonio Abad y la garita de la Viga: "todo este trozo pudiera trasladarse a dicho barrio de Santa María y Lagunilla, parajes sanos y despoblados". 64

Además de la erección de nuevos curatos y de la transformación, por tanto, de las demarcaciones precedentes, la medida más importante de toda la reforma parroquial sería la fijación territorial de los fieles con independencia de su naturaleza, quedando sujetos a la parroquia de su lugar de residencia. Tal idea la

63 Alzate, "Papel”, ff. 2v.-3r.

${ }^{64}$ Alzate, "Papel”, ff. 2v.-3v. 
expresó Alzate como lo más urgente y sencillo, interviniendo sobre las parroquias de indios de Santa Cruz, San Sebastián y Santa María "asignándoles territorios y los feligreses comprendidos en ellos de todas las calidades" ${ }^{65}$ Haciendo alusión a una imagen de la ciudad -quizá a aquel plano levantado hacia 1767 $\mathrm{y}$, probablemente, con una distribución de dichas colaciones similar a la del proyecto de enero de 1769-, las tres feligresías referidas destacaban por "la proporción en que están" y el "ligero perjuicio de las parroquias confinantes", motivo por el que "se podrá proceder a un arreglamento firme y de conocida utilidad para ellas y sus feligreses". ${ }^{66}$

De esta forma, se solucionaba el problema de la pertenencia dispersa de los fieles según su naturaleza y los cambios de identidad de los indios que no se reconocían como tales. Con todo, se acabaría imponiendo que los indios quedasen inscritos en libros sacramentales separados de los "españoles, mestizos, mulatos y otras castas", facilitando el trabajo a la Real Hacienda, "para que por esos y su padrón se puedan conocer los tributarios". ${ }^{67}$ Con la imposición del orden territorial, por encima de la lengua o calidad de los habitantes, se avanzaba en la creación de un espacio urbano más uniforme y más fácil de gestionar espiritual $\mathrm{y}$ fiscalmente. Se daba continuidad, no obstante, a un proyecto

\footnotetext{
${ }^{65}$ Alzate, "Papel”, f. 4r.

66 Alzate, "Papel”, ff. 1v.-2r. Según la distribución que se haga en 1769, por un lado, Santa María y San Sebastián le quitaban terreno al Sagrario y a Santa Catarina y, por otro, Santa Cruz crecía sobre territorio del Sagrario y de San Miguel. Al concluir el proceso de reforma, en 1772, Santa Cruz y Santa María mantuvieron la forma asignada en 1769, mientras que San Sebastián perderá su regularidad en beneficio de las vicarías del Sagrario.

${ }^{67}$ Reunión de Lorenzana con los párrocos de la ciudad, 14 de diciembre de 1771. AGN, TC, vol. 8, exp. 4, f. 134r.-v. Moreno, "Los territorios", p. 6. Véase "Carta en que se manda a los párrocos asistan al padrón, que se forma de orden de SM para la paga de tributos", 29 de diciembre de 1769, en Lorenzana, Cartas, pp. 117-118. Mazín y Sánchez de Tagle, Los "Padrones". SiERra, El cardenal, pp. 138-139.
} 
general de "hispanización" o "segunda aculturación", como lo definió Serge Gruzinski, orientado a "cristianizar a los indígenas e intensificar su participación a la vida social y económica del país". ${ }^{68}$ Un proceso en el que buena parte de las intervenciones se dirigieron contra las "culturas indígenas coloniales", fraguadas en el sincretismo, y cuyo último fin, más que cristianizar, fue "conseguir la prosperidad del país, mejorando la educación y desterrando la ignorancia". ${ }^{69}$

Mirando al sostenimiento económico de las nuevas parroquias conjuntas, según Alzate, Santa Cruz y San Sebastián se podrían mantener fácilmente gracias a las cofradías recientemente fundadas tras su secularización. En el caso de Santa María -al igual que en la parroquia de San Pablo, apenas secularizada, o en la Santa Veracruz- no bastaría con fijarle territorio y agregarle "gente de razón", sino que habría que promover la fundación de hermandades. Así se costeaban los tradicionales curatos de españoles de San Miguel y Santa Catarina, gracias a las asociaciones piadosas formadas por gentes acaudaladas procedentes de la feligresía del Sagrario..$^{70}$ De esta forma, si se planteaba "dividir en más" estas parroquias de españoles, "como sería útil para el buen régimen", sería oportuno "considerar lo expuesto acerca de sus fondos para la fábrica material y espiritual" ${ }^{71}$ Aludiendo a la referida idea planteada por Lorenzana en abril de $1767,{ }^{72}$ si el Sagrario se fragmentaba "como conviene en cuatro o cinco" circunscripciones, contestaba Alzate que, aunque los sacerdotes pudiesen recibir una buena congrua, no habría suficientes

\footnotetext{
${ }^{68}$ GruZinski, "La segunda”, pp. 175-201, la cita es de la p. 185.

69 AGN, $H, 493$, exp.12, f. 117, citado en GruZINSKI, "La segunda”, p. 192.

70 Véase el minucioso estudio de Pescador, De bautizados, sobre la composición social de la parroquia de Santa Catarina.

${ }^{71}$ Alzate, "Papel”, ff. 19v.-21v.

72 Informe de la contaduría general, Madrid, 19 de enero de 1770. AGI, $M$, 727 , f. 1 r.-v.
} 
ingresos para mantener la fábrica. ${ }^{73} \mathrm{El}$ quid de toda la discusión residía en la dificultad de fijar un espacio poblacionalmente híbrido, económicamente sostenible y territorialmente manejable para la cura de almas. Por una parte, la nimia extensión de territorios, y multitud excesiva de feligreses, dificulta al párroco su conocimiento y asistencia. Por otro, se hace precisa esta extensión y multitud, porque sin ella carecería de una muy moderada congrua. ${ }^{74}$

Como imagen que bien podría condensar esta primera etapa de ensayos y propuestas, el "Plano en que se comprehende el Curato de Yndios intitulado de Señor San Joseph", atribuido a José Antonio de Alzate, ejemplifica la mirada a los problemas de la administración parroquial de México justo antes de la reforma de Lorenzana (mapa 3). ${ }^{75} \mathrm{~A}$ mediados de 1757 se había determinado cómo, al quedar vacante un curato de los regulares, los obispos y los virreyes dispondrían de su provisión para cederlo al clero secular. ${ }^{76}$ En ese sentido, el 28 de diciembre de 1768, habiendo pasado cuatro años del fallecimiento del franciscano que lo regentaba, Lorenzana respondió “con justificación” a las demandas del monarca acerca de las providencias para la secularización de San José.77 Deseoso de su exoneración, el arzobispo le remitió varios testimonios y "para informar quan conveniente

\footnotetext{
73 Alzate, "Papel”, ff. 18v.-19r.

74 Alzate, "Papel", f. 6v.

75 "Plano en que se comprehende el Curato de Yndios intitulado de Señor San Joseph, cituado en esta Ciudad de Mexico, dispuesto por orden del Yllustírimo Señor Doctor Don Fray Antonio de Lorenzana y Buytrón, Arzobispo de esta Santa Iglesia Metropolitana", 1768. AGI, MP, M, 247. Al dorso se lee: "Vino con carta del Arzobispo de México, de 28 de diciembre de 1768". El plano tiene unas dimensiones de $52.5 \times 50 \mathrm{~cm}$. Véase una reseña del plano en LoMBARDO, Atlas, pp. 54-55 y Mundy, “The Images”, pp. 60-61.

${ }^{76}$ Reales cédulas de 1 de febrero de 1753 y de 23 de junio de 1757. AGI, $M$, 727.

77 Real cédula de 16 de agosto de 1768. AGI, $M$, 727. Álvarez-Icaza, "La secularización”, p. 312.
} 


\section{Mapa 3}

“PLANO EN QUE SE COMPREHENDE EL CURATO DE YNDIOS INTITULADO DE SEÑOR SAN JOSEPH"

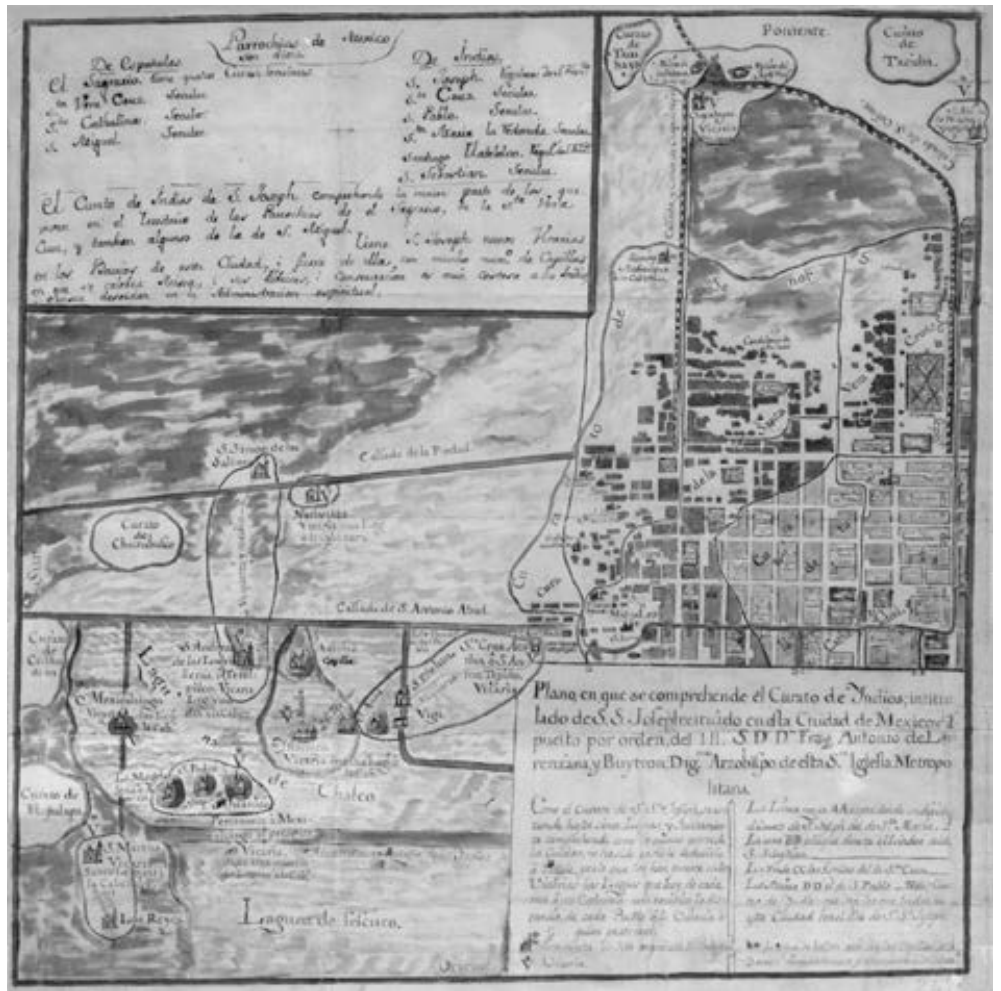

será su secularización, según se me encarga, acompaño mapa de su comprehensión" ${ }^{78}$

Al condensar el panorama general de las parroquias, en la cartela superior del plano se indican los nombres y situación de las diez parroquias de la ciudad, dividiéndolas entre españoles e indios, e indicando si son regentadas por seculares o por

${ }_{78}$ Carta de Lorenzana al rey, 28 de diciembre de 1768. AGI, $M, 727$, f. $1 \mathrm{r}$. 
regulares. Se explicita cómo el curato de San José de los Naturales no solo comprendía los feligreses que vivían dispersos en el recinto de varias parroquias de españoles, sino también los de "nueve Vicarías en los Barrios de esta Ciudad, i fuera de ella, con mucho número de Capillas en que se celebra Misa". Aquellas eran las barriadas de "Santa Cruz Acatlán, San Antonio de las Huertas, Chapultepec, San Andrés Tetecpilco, alias Las Ladrilleras, Nativitas, Yztacalco, Santa Martha, Mexicaltzingo y últimamente San Juanico (división del antecedente)". ${ }^{79}$

Puesto que uno de los argumentos para la secularización y posterior redistribución de los espacios era su difícil administración y los problemas económicos, pues "sus fábricas, $\mathrm{i}$ conservación es mui costosa a los indios, i caussa desorden a la Administración espiritual", 80 la composición del mapa se dirige a visualizar este caos. Sobre las parroquias de españoles (Veracruz, San Miguel y el Sagrario, cada una de un color) se impone como un recorte la feligresía de San José. Los linderos de dichas colaciones no eran, en absoluto, regulares, sino que seguían los principales desagües, en otro tiempo confín de la ciudad de los españoles y, para entonces, causa de desconcierto y confusión. ${ }^{81}$ Si en el "Plano de la Ymperial México" (mapa 1) -con el que guarda un notable parecido formal- se acentúa la rectitud de las calles, como evidencia de una nueva distribución racional, en este mapa se enfatizan las líneas curvas y sinuosas, el acecho del agua y la irrepresentable dispersión de las vicarías. En este sentido, reforzando la idea de un poblamiento diseminado y desestructurado, la leyenda explica cómo se ha comprimido el espacio izquierdo del mapa y, como solución, se ha indicado la separación entre los barrios:

79 Testimonio del notario público del Provisionato, México, 28 de diciembre de 1768. AGI, $M, 727$.

${ }^{80}$ Cartela superior izquierda del "Plano ... de San Joseph". AGI, $M P, M, 247$.

81 Protesta de los curas de españoles al rey, México, 10 de noviembre de 1771. AGI, $M, 2659$, f. 2 r. 
Como el curato de Señor San Joseph se extiende hasta cinco leguas y juntamente comprehende como la quarta parte de la ciudad, no ha sido posible reducirlo a pitipié, por lo que se han puesto en las vicarias las leguas que hay de cada una a su cabezera como también la distancia de cada pueblo a la vicaría a quien pertenece. ${ }^{82}$

Como se ha dicho, la secularización del gran curato de San José se planteó como un primer paso en la transformación espacial de la ciudad. Tras su ejecución, quedaría “maior proporción para señalar territorio fixo a cada uno de los curatos de esta ciudad y [...] se puede establecer el mejor gobierno eclesiástico que también contribuirá para el político".${ }^{83}$ Como era de esperar, los franciscanos de la provincia del Santo Evangelio se opusieron a la secularización de su doctrina y, para ello, contraargumentaron echando mano de la historia y la tradición. ${ }^{84}$ Los religiosos rogaron al monarca el mantenimiento de San José “por pura gracia, en señal y memoria de haber sido su religión la primera que pasó a este reino a la predicación y conversión de los naturales de nuestra santa fe". ${ }^{85}$ Finalmente, aunque les fue respetado su convento, los religiosos no pudieron impedir la secularización del curato en 1770 , cuya entrega, en palabras del virrey, "se hizo con la más quieta y pacífica conformidad”. ${ }^{86}$

${ }^{82}$ Cartela inferior derecha del "Plano... de San Joseph". AGI, MP, M, 247.

83 Carta de Lorenzana al rey, 28 de diciembre de 1768. AGI, $M$, 727, f. 2 r.

84 Álvarez-Icaza, La secularización, pp. 312-313; García, "Re-formar", p. 254.

${ }_{85}$ Carta de Lorenzana a Julián de Arriaga, secretario de Indias, México 27 de mayo de 1771. AGI, $M, 727$, f. $1 \mathrm{v}$.

86 Testimonio del virrey marqués de Croix, México, 28 de junio de 1770. AGN, CV, serie I, vol. 4, f. 295r.-v. Álvarez-IcAZA, La secularización, p. 313. 
CARTOGRAFÍA DEL PLAN PARROQUIAL DE ALZATE (1769)

El diseño de las nuevas subdivisiones parroquiales no fue una tarea sencilla. Tanto Alzate como Lorenzana eran conscientes de que, al "echar las líneas o términos por tales y tales calles, para el reglamento de dos o tres parroquias", se podía perjudicar la jurisdicción de las limítrofes, lo que acarrearía no pocos conflictos con los párrocos damnificados. ${ }^{87}$ Tras meses de trabajo, el 23 de enero de 1769, el bachiller presentó a su arzobispo un plano y una memoria, "que he formado más fácil y de no difícil ejecución”, con la nueva distribución de las colaciones (mapa 4). ${ }^{88}$ La validez del diseño de Alzate se sustentaba, por un lado, en el buen manejo de las fuentes disponibles pero, sobre todo, en el conocimiento empírico de la urbe y su propia experiencia "discurriendo una por una" las calles de la ciudad: ${ }^{99}$

Para su formación he tenido presentes las mejores descripciones thopographicas de esta ciudad, y no fiándome solo en ellas, personalmente y con el mayor sigilo que pidieron estas materias, he rexistrado todos los barrios, callejones, hermitas o capillas que se hallan en el recinto de esta ciudad y que van todas en el mapa sin omitir alguna. ${ }^{90}$

Al igual que los borradores y proyectos que Alzate trazó meses atrás, tampoco conocemos ningún ejemplar o versión de este plano. Sabemos de él por las descripciones textuales que se enviaron al virrey y al Consejo de Indias acompañando una copia del mapa, por las referencias hechas durante las discusiones y por diseños posteriores de terceros, donde se vislumbran reflejos e influencias de los planos perdidos de Alzate en los

\footnotetext{
87 Alzate, "Papel”, f. 1v.

${ }^{88}$ Alzate, "Memoria", f. 1r. Tachado en el original.

89 Alzate, "Papel”, f. 17v.

90 Alzate, "Memoria", f. 1r. Tachado en el original.
} 
Mapa 4

PROYECTO ORIGINAL DE ALZATE, SEGÚN MEMORIA DEL 23 DE ENERO DE 1769

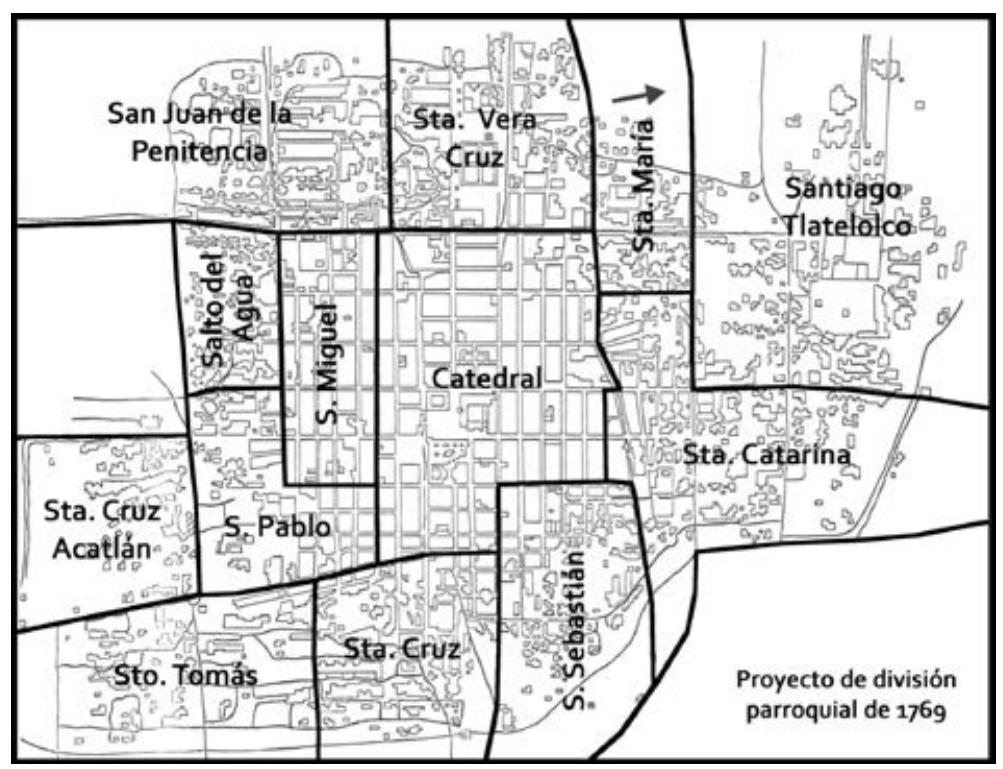

que se recogió su frustrado plan. La hechura del original debió guardar bastantes similitudes con el "Plano de la Ymperial México" (mapa 1), cuya planta se levantó a partir de este, tal y como indicaba su leyenda: "dispúsolo en 1769 años". Esto nos habla de una estructura planimétrica validada y autorizada, que se empleó tanto como modelo de los duplicados -remitidos a las autoridades junto con los memoriales- como de soporte para el conocido ejemplar de 1772. Por otro lado, entre ambos mapas, la coincidencia del identificador cromático asignado a cada uno de los curatos es muy reveladora. Salvo las tres vicarías del Sagrario, novedad que se incorpora en el edicto de 1772, los colores que se puntualizan en las explicaciones del mapa de 1769 concuerdan con las colaciones del plano conservado. Si 
bien algunas tonalidades del ejemplar del Museo Franz Mayer se han oscurecido y han perdido su viveza con el tiempo, es fácil reconocerlas a partir de dichas descripciones. No obstante, entre ambos planos se presentan variaciones nominales y territoriales en algunas feligresías, las cuales analizaremos a partir de la reconstrucción del diseño perdido.

El proyecto reformador de Alzate recogió las cuestiones fundamentales que habían sido planteadas desde meses atrás. La principal novedad fue la extensión del criterio de parroquialidad conjunta de todos los vecinos, sin importar su naturaleza, a todas las feligresías. La segunda medida fue la creación de nuevas parroquias, dividiendo y reasignando los espacios de las ya existentes. Se establecieron colaciones más pequeñas y de más fácil manejo para los sacerdotes, pero que, al mismo tiempo, les dejasen una buena congrua. ${ }^{11}$ Así, en lugar de las diez parroquias precedentes (cuatro de españoles y seis de indios), se demarcaron un total de 13. Además de las disposiciones dirigidas al mejor control de los fieles, desde una perspectiva más urbanística, una tercera innovación fue la racionalización espacial de las circunscripciones eclesiásticas. Esto es, una decidida preferencia por el orden y la simetría que borró las antiguas divisorias parroquiales. Alzate ejemplificó este problema explicando cómo "muchas casas situadas en las orillas de las acequias pertenecen a dos o mas parroquias, por lo que se han visto tres sagrarios en una misma casa". Y lo ilustró con el caso de la cuadra sita en la calle del Zacate, a espaldas del convento de San Francisco, que estaba atravesada por el conducto del agua. Allí se podrían llegar a encontrar hasta tres párrocos, pues los vecinos del norte de la acequia estaban adscritos a la Catedral, a la de Veracruz los del sur y a la de San José los indios. ${ }^{92}$

91 Zahino, Iglesia, p. 56; Moreno, “Los territorios”, p. 14.

92 Alzate, “Memoria”, ff. 2v.-3r. 
Como solución, su proyecto optará, en tanto sea posible, por las líneas rectas y las formas proporcionadas, estrategia mucho más acorde con la concepción original de la planta de la ciudad $\mathrm{y}$ con el deseo general de orden al que aspiraban el prelado y las autoridades civiles. ${ }^{93}$ En ese sentido, se observa cómo la composición del "Plano de la Ymperial México" tiende a reforzar la centralidad urbana en torno del Sagrario, de la misma forma que logra visualmente un aspecto armónico: la dispersión de los barrios queda aparentemente equilibrada en el eje que va del extremo superior derecho al inferior izquierdo, mientras que el oscurecimiento de la mitad superior izquierda contrarresta el peso de la mitad opuesta -en el costado inferior derecho-, ocupada por las cartelas. ${ }^{94}$

Las circunscripciones planeadas por el bachiller buscaban redistribuir el espacio urbano en unidades coherentes en población y extensión. Para ello, Alzate se sirvió de los padrones parroquiales. ${ }^{95}$ Sin ser conscientes de su finalidad, los párrocos tuvieron que remitir "copias de las matriculas que anualmente hacen para el cumplimiento del precepto de la Iglesia", es decir, los documentos donde se recogía la observancia anual de la comunión y confesión de los fieles por Pascua de Resurrección. ${ }^{96}$ Elaborados minuciosamente, y no sin dificultad por los frecuentes fraudes, con tales registros Alzate pudo estimar tanto el cómputo global de los fieles como la proporción de los habitantes

\footnotetext{
93 "Por el mal gusto de fabricar sus casas los naturales van cortando, y afeando la formación de las calles de sus barrios [...] y para precaver este perjuicio en la policía también conduce que todas las parroquias estén con un mismo arreglo, y aprehendan los naturales a construir sus casas a el modo de los españoles". Carta de Lorenzana a De Croix, México, 25 de enero de 1769. AGI, M, 727, ff. 3v.-4r. Citado en Zahino, Iglesia, pp. 51-52.

${ }^{94}$ VillafaÑe, Introducción, p. 188.

${ }^{55}$ Mazín y Sánchez de Tagle, Los “Padrones", p. 23.

${ }_{96}$ Protesta de los curas de españoles al rey, México, 10 de noviembre de 1771. AGI, $M, 2659$, f. 3v. Sobre el precepto anual, véase TAYLOR, Ministros, pp. 359-362.
} 
según su calidad y posición socioeconómica. Probablemente, junto con la memoria y el plano, facilitase dichos cálculos al arzobispo pues, unos días más tarde, Lorenzana controlaba la suma total de comulgantes, indios y españoles; por ejemplo, en la parroquia del Sagrario: "el número de feligreses de comunión por los padrones que han presentado asciende a treinta y quatro mil ciento setenta y ocho según la común inteligencia". ${ }^{97}$

Concibiendo la parroquia como una jurisdicción territorial moderna, Alzate configuró el plano de las 13 feligresías, justificando la racionalidad de cada una de las divisorias por su extensión espacial, cualidad poblacional y forma cartográfica. En el corazón de la urbe fijó el ámbito de la parroquia del Sagrario que, aunque perdía un poco de su antigua extensión, "se le recompensa con los indios que en la actualidad pertenecen a otras parroquias". El territorio, pigmentado en "color nácar", resultaría "bien proporcionado y con sus límites bien conocidos", incluso si se colocase a uno de los curas del Sagrario en la antigua iglesia jesuita de la Profesa..$^{98} \mathrm{~A}$ su mediodía, estableció -en "color amarillo verdoso"- el curato de San Miguel, antes de españoles. Observando el mapa, quedaba "reducido a un quadrilongo perfecto" y, "aunque parezca pequeño", en verdad, se le había sumado una buena proporción de indios. ${ }^{99}$ Junto a éste, delimitó en "azul claro" la jurisdicción de San Pablo que

97 Carta de Lorenzana a De Croix, México, 25 de enero de 1769. AGI, $M, 727$, f. 1v. La cifra es muy similar a los 32668 fieles que recoge el Padrón de 1777 donde, aun señalándose por separado los de cada categoría, se suma el total de los moradores en cada circunscripción. "Padrón exacto de todas las personas que hay en este Arzobispado de México, con distinción de Clases, Estados y Calidades formado en ejecución puntual de Real Orden de 10 de noviembre de 1776, con arreglo a los padrones particulares presentados por los Curas y Superiores de las Religiones, Conventos, Colegios y Hospitales. México y junio 26 de 1779”, en Sánchez Santiró, Padrón.

98 Véase, como ejemplo, la transcripción de los límites de este curato en Sierra, El cardenal, pp. 140-141.

99 Alzate, "Memoria", ff. 4r.-5r. 
"así dispuesto será de una fácil administración y de competente número de feligreses". Al este de la Catedral dispuso las nuevas lindes de Santa Cruz y de San Sebastián. La primera, de "color carmesí", "queda mucho mejor, pues le resta casi el mismo territorio que antes tenía por lo perteneciente a indios, con el agregado de españoles, mulatos, etc.”, y la segunda, de "color de esmeralda", "comprehendería un quadrado con poca diferencia”. ${ }^{100} \mathrm{Al}$ norte del recinto catedralicio demarcó, en "ocre claro", la colación de Santa Catarina Mártir, muy cercenada pero compensada con algunos barrios de indios que fueron de Santiago Tlatelolco. ${ }^{101}$ La parroquia de la Veracruz, de "color de ocre obscuro", la extendió hacia el poniente de la ciudad superando, incluso, los márgenes de su propio dibujo: a pesar de que la jurisdicción de la Veracruz se prolongaba por la calzada de Tacuba hasta San Cosme, Alzate no quebró la armonía y la proporción deseada en su plano, advirtiendo que dicha población "no se ha comprehendido en el mapa, por ser cosa de poca entidad y que al mismo tiempo necesitaba extenderlo a más de una tercia parte". ${ }^{102} \mathrm{Al}$ norte de este último curato emplazó -en "verde obscuro"- la pobre y deshabitada parroquia de Santa María que, gracias a la agregación territorial, "resucitará de las agonías que padece". ${ }^{103} \mathrm{Y}$ en el extremo más septentrional -en "color naranjado"- reubicó Santiago Tlatelolco que, aunque "tiene en el plano una extensión dilatada respecto de otros, es por hallarse [...] sumamente despoblado". ${ }^{104}$ Con todo, se le desgajaron algunos pueblitos para agregárselos a otros curatos de fuera de la ciudad.

100 Alzate, “Memoria”, ff. 9r.-10r.

101 Sobre la población incorporada a este curato, véase PESCADor, De bautizados, p. 30.

102 Alzate, “Memoria”, f. 5v.

103 Alzate, “Memoria”, f. 6v.

104 Alzate, “Memoria”, f. 13v. 
De nueva creación, pintó en "color obscuro", al sur de la urbe, la parroquia de la Purísima Concepción del Salto del Agua, hasta entonces capilla auxiliar de la Veracruz. Aun teniendo pocos vecinos españoles y numerosos indios provenientes de San José, el bachiller estimó que "este curato será muy bueno por tener bastante población en su recinto". Al mediodía de San Pablo implantó la nueva parroquia de Santa Cruz de Acatlán o San Antón Tepito que, en amarillo sobre el mapa, destacaba por ser prácticamente "un quadrado", amén de contar con un buen número de feligreses. La de Santo Tomás -teñida de morado-se fundó a su oriente, "en muy buena proporción". Y al suroeste, de "color de rosa", quedó establecida la parroquia de San Juan de la Penitencia que, en la práctica, asumía buena parte de la antigua jurisdicción de San José, incluido el pueblo de Romita. Con cierta indeterminación sobre los fieles más dispersos y alejados del casco, su límite era "al sur y al poniente lo despoblado". ${ }^{105}$

Según advirtió el mismo Alzate, no reservó ningún área al curato de San José "por la dificultad de acomodarle territorio" y prefirió dividirlo entre otras circunscripciones. ${ }^{106}$ El plan para desintegrar la jurisdicción de los franciscanos -en proceso de secularización- comenzó, de manera simbólica, con el intento de borrar su nombre: "Llamo así a este curato [San Juan de la Penitencia] por comprender el barrio asíllamado, pertenece por lo que mira a los españoles al de la Veracruz, y por los indios al de el Señor San José”. La intervención se justificó buscando, por un lado, el beneficio de los indios, "todo aquel poblado está reducido a unos callejones [...] en el que viven como moros sin señor", y por otro, el acomodo de las demás parroquias. ${ }^{107} \mathrm{No}$ obstante, aquella decisión no fue comprendida en la corte y el

\footnotetext{
105 Alzate, "Memoria”, ff. 7r.-9r.

106 Alzate, “Memoria”, f. 14v.

107 Alzate, “Memoria”, f. 7v.-8r.
} 
arzobispo promotor quedó indignamente retratado: "su deseado fin, qual es, el de despojar enteramente a la Provincia del Santo Evangelio de la parroquia de San Joseph de Indios, por el raro término de refundir su territorio en otras inmediatas". 108 Contra esta medida, el Consejo de Indias acabó por imponer su criterio y, una vez secularizado, el título de San José se mantendría dando nombre al territorio que Alzate dedicó a San Juan.

Con este medio queda allanada la dificultad de asignar territorio a San Joseph, porque no se pide en la circunferencia del convento, en lo que estaba el embarazo, sino se le aplica el mismo que tiene, y está señalado por el muy reverendo arzobispo [...] quedando la parroquial de San Joseph con el barrio de San Juan por cabezera (como se registra en el mapa) ya no hay confusión de territorios ni feligreses. ${ }^{109}$

Precisamente, la distinción tipográfica con la que aparece la iglesia de San Juan de la Penitencia en el "Plan de la Ville de Mexico”, publicado en 1772 en Voyage en Californie, obra póstuma de Chappe d'Auteroche, es uno de los detalles que permiten rastrear las cualidades del mapa perdido de Alzate en otros ejemplares (mapa 5). ${ }^{110} \mathrm{El}$ astrónomo francés Jean Chappe d'Auteroche viajó a México en 1769 para realizar observaciones del paso de Venus. En la capital del virreinato, antes de partir hacia Baja California, conoció a José Antonio de Alzate, quien le facilitó documentos científicos, de historia natural y algunos mapas, entre los cuales pudo ir el original en el que se basó el

108 Informe de la contaduría general, Madrid, 19 de enero de 1770. AGI, $M$, 727, f. $5 \mathrm{v}$.

109 Informe de Manuel de la Vega, comisario de Indias, Madrid, 17 de julio de 1770. AGI, $M, 727$, ff. 4v.-5r.

110 "Plan de la Ville de Mexico", 1772, grabado por Pierre Claude de La Gardette. 
Mapa 5

“PLAN DE LA VILLE DE MEXICO”, 1772

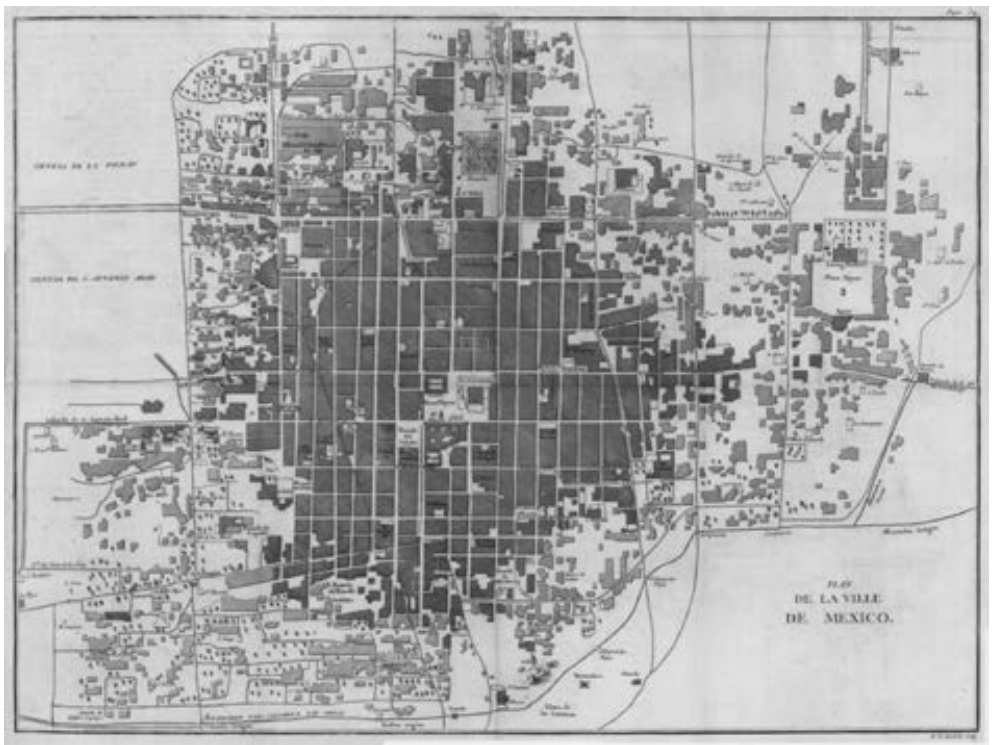

plano impreso. ${ }^{111} \mathrm{Al}$ fallecer el abate Chappe, apenas acabando la expedición, sus anotaciones fueron recuperadas por el ingeniero y geógrafo del rey Jean Pauly, quien las remitió a la Academia Real de Ciencias de París junto con los materiales proporcionados por Alzate. ${ }^{112}$ Por su lado, el sabio novohispano también enviaría a Francia sus propias mediciones del tránsito venusino y otros cálculos astronómicos. ${ }^{113}$ Parte de dichos trabajos alzatianos fueron editados en Voyage en Californie, volumen que sería preparado por el conocido cartógrafo y astrónomo Jean-Dominique Cassini. En esa publicación vio la luz el "Plan de la Ville de Mexico", elaborado a partir de una versión

111 Bernabéu, Las huellas. Toussaint, Gómez de Orozco y Fernández Planos, pp. 25-26.

112 Chappe, Voyage, p. 54.

113 Trabulse, Historia, pp. 462-466. 
del plano de Alzate de 1769 y, por tanto, con una hechura gráfica muy similar al ejemplar manuscrito del Museo Franz Mayer. ${ }^{114}$

Sin dudarlo, Manuel Orozco y Berra celebró aquel plano como "obra de nuestro esclarecido compatriota D. Antonio Alzate". Lo definió "muy superior, bajo el punto de vista científico, a los trabajos de Fer y de Villaseñor", puesto que "el dibujo es bueno, y el terreno está comprendido y expresado". ${ }^{115}$ En el mapa impreso, el texto que da nombre a la iglesia de San Juan de la Penitencia -pretendido título de la parroquia según el proyecto de Alzate de 1769- destaca por su ubicación (invadiendo el espacio vacío de la plaza y dilatándose por la calle próxima) y por su letra redonda y de mayor tamaño, en comparación con el resto de emplazamientos del barrio (escritos en cursiva, como la aún parroquia de San José). La estrategia visual que en un primer momento pudo haber empleado Alzate -y que habría quedado fosilizada en la versión de Cassini- se desvanecería en el plano manuscrito de 1772, pues no llegó a consolidarse la advocación de la nueva feligresía (mapa 6).

Alberto Saladino ha advertido cómo las primeras obras de José Antonio de Alzate tuvieron un carácter mucho más religioso y teológico que su producción posterior. ${ }^{116}$ En 1768 , por ejemplo, mientras preparaba el plan de reforma parroquial, publicó "Reflexiones sobre la utilidad que las bellas letras pueden sacar de la Sagrada Escritura y sobre la primera edad del mundo", 117 donde rastreó los fundamentos de las ciencias y las

${ }^{114}$ En la reconstrucción del diario de Chappe que imprimió Cassini debió emplearse esta versión del plano de Alzate (mapa 5). La ausencia de rosa de los vientos hizo errar al editor quien, al explicar los principales lugares de la capital, consideró que "al norte de la ciudad, hacia los suburbios, está el paseo público o Alameda". Interpretó, por tanto, que la parte superior de la imagen se correspondía con el septentrión, en lugar de ser el occidente. CHAPpe, Voyage, p. 29.

115 Orozco y Berra, Memoria, p. 7, mapa XVII.

116 Saladino, El sabio, p. 42.

117 Diario Literario, 26 de marzo de 1768, en Alzate, Gacetas, pp. 7-15. 


\section{Mapa 6}

DETALLE DE SAN JUAN DE LA PENITENCIA EN EL “PLAN DE LA VILLE DE MEXICO” Y EN EL “PLANO DE LA YMPERIAL MÉXICO”

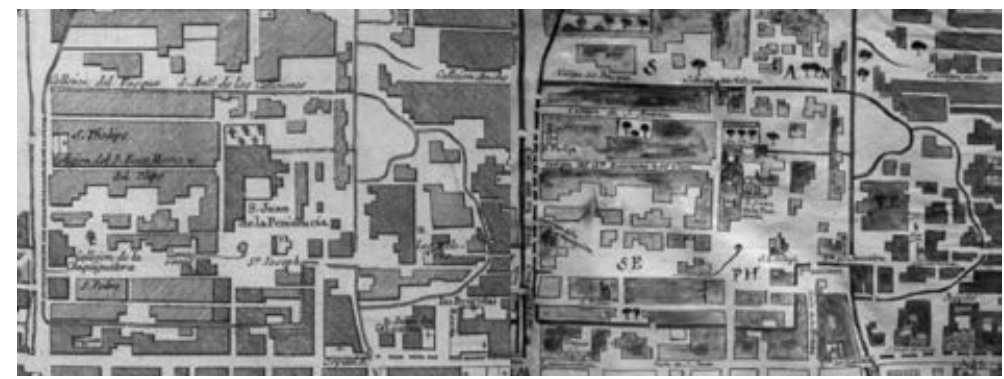

artes en los primeros libros de la Biblia. En esa línea, no sería desdeñable conjeturar algún culteranismo bíblico en la elaboración de su primer proyecto urbano. Su compleja personalidad, joven sacerdote y amante del saber, podría haberle llevado a escoger el número de 13 parroquias con alguna resonancia evangélica, una por cada uno de los 12 apóstoles más otra, Cristo o la Virgen María, representada por el Sagrario de la Catedral. Sin embargo, en mi opinión, el análisis de la descripción cromática de los curatos, idéntica en todas las versiones de sus planos, apunta a una recreación simbólica de la ciudad mucho más elaborada.

En primer término, sorprende el parecido de los colores empleados entre sí: "color obscuro", "naranjado", ocres claro y oscuro; amarillo, “amarillo verdoso”, verde oscuro y esmeralda; nácar y carmesí, rosa y morado. Alzate bien podría haber escogido otros tonos más diferenciables, haber cambiado los pigmentos en traslaciones posteriores del plano -si es que el problema fue inicialmente la falta de tintas-, o haber replanteado su distribución en el soporte para lograr mayor claridad, a no ser que esos y no otros colores tuviesen un significado especial que 
el bachiller hubiese querido mantener en todos sus diseños. ${ }^{118} \mathrm{Si}$, con su plan, Alzate estaba creando la nueva ciudad de México, no es de extrañar que en su mente resonase la nueva ciudad por excelencia: la Nueva Jerusalén, descrita en el libro del Apocalipsis, cuyas murallas se erigen sobre 12 pilares, cada uno con el nombre de un apóstol y decorado con piedras preciosas:

El primer pilar era de jaspe; el segundo de zafiro; el tercero de calcedonia; el cuarto de esmeralda; el quinto de sardónica; el sexto de sardio; el séptimo de crisólito; el octavo de berilo; el noveno de topacio; el décimo de crisoprasa; el undécimo de jacinto, y el duodécimo de amatista. ${ }^{119}$

En particular, en el caso de Nueva España, la iconografía hierosolimitana se popularizó como un recurso moralizante, de claras connotaciones escatológicas y marianas. En la plástica del barroco criollo, la urbe mexicana remitía a la celeste no solo por su marcada geometría, sino por una identificación como tierra de promisión, bendecida por la presencia de la Virgen -concretamente, la de Guadalupe, bajo su apariencia de Virgen del Apocalipsis- ${ }^{120}$ Aquella imagen, con un significado alegórico y urbanístico, pudo servir de referente a Alzate para la coloración de su "nueva" ciudad de México, al igual que a otros artistas y

118 Para el posterior "Plano de la Ymperial México", Mundy, “The Images”, pp. 62-63, plantea una sugerente lectura de los contrastes de tonalidades y la creación de jerarquías cromáticas entre las parroquias.

119 Apocalipsis, 21, 19-20. La alegoría de la Nueva Jerusalén recuerda al pectoral de Aarón (Éxodo, 28, pp. 15-20), también con 12 incrustaciones y varias piedras en común. En la actualidad, ciertas rocas son difíciles de identificar y otras se consideran una misma piedra, siguiendo criterios modernos de clasificación mineral. Según las ediciones modernas de la Biblia, la sardónica aparece como ágata y el sardio como cornalina. El pasaje reproducido es una traducción lo más literal posible del texto latino de la Nova Vulgata.

120 Rubial, "Civitas Dei”, pp. 33-34. 
teóricos del arte de su tiempo. ${ }^{121}$ Como recientemente ha escrito Michel Pastoureau, ampliando los horizontes de la historia cultural, para el historiador, estudiar el color es tanto abordar las palabras, los pigmentos o las técnicas de pintura, como tratar "de los códigos y sistemas que lo acompañan, de los reglamentos que emanan de las autoridades, de la moral y los símbolos que instauran las religiones, de las especulaciones de los científicos, de las invenciones de los artistas". ${ }^{122}$ Así pues, siguiendo a Emiliano Fernández Vallina, quien estudió los valores cromáticos y simbólicos atribuidos a los minerales en diferentes tratados, ${ }^{123}$ podemos establecer una clara correlación entre las piedras del Apocalipsis y la descripción de las tonalidades presentada por José Antonio de Alzate (tabla 1).

No es casual que el único color cuya descripción sea un material de origen no mineral, el nácar, corresponda a la parroquia del Sagrario. El nácar, "la concha en que se cría la perla", ${ }^{124}$ en el arte y la literatura, ha representado a María como vientre que encarnó a Cristo, tradicionalmente adoptando una tonalidad blanca, color inmaculado y virginal. ${ }^{125}$ Sin embargo, en el plano de 1772 se observa cómo el centro del Sagrario se colorea en rojo y se describe como "nácar" en una pequeña nota en el extremo inferior derecho. Esto se debe a que Alzate empleó el acostumbrado color nácar rojo de la Nueva España, extraído del bivalvo Spondylus americanus, conocido en náhuatl como xochipaltapachtli, que habita en el Golfo de México, en las costas

${ }^{121}$ Por citar un ejemplo novohispano, Cristóbal de Villalpando pintó en 1706 Mística Ciudad de Dios, empleando idénticos colores en las murallas de la Jerusalén celestial. Museo Regional de Guadalupe, Instituto Nacional de Arqueología e Historia de México.

122 Pastoureau, Los colores, p. 244.

123 FERnÁNDEz, "Una guirnalda”, pp. 339-341.

124 Diccionario de autoridades, s.v. "nacar".

125 Véase un ejemplo y la explicación de la metáfora en CaLderón, La piel, pp. 144-145. 


\section{Tabla 1}

COLORES DEL PLANO DE ALZATE

\begin{tabular}{|c|c|c|c|}
\hline $\begin{array}{l}\text { Piedra preciosa } \\
\text { (Ap. 21, 19-20) }\end{array}$ & $\begin{array}{l}\text { Descripción } \\
\text { cromática en } \\
\text { la tratadistica }\end{array}$ & $\begin{array}{l}\text { Color asignado } \\
\text { por Alzate }\end{array}$ & $\begin{array}{l}\text { Curato } \\
\text { correspondiente }\end{array}$ \\
\hline Jaspe & $\begin{array}{l}\text { De varios colores, } \\
\text { tonos rojizos o } \\
\text { verdosos }\end{array}$ & Naranjado & $\begin{array}{l}\text { Santiago } \\
\text { Tlatelolco }\end{array}$ \\
\hline Zafiro & Azul celeste & Azul claro & San Pablo \\
\hline Calcedonia & De pardo a gris & Ocre oscuro & Santa Veracruz \\
\hline Esmeralda & Verde oscuro & Esmeralda & San Sebastián \\
\hline Sardónica [ágata] & Gris ceniza & Color oscuro & Salto del Agua \\
\hline Sardio [cornalina] & Rojo & Carmesí & Santa Cruz \\
\hline Crisolito & $\begin{array}{l}\text { Verde agrisado, } \\
\text { amarillo o azul } \\
\text { marino }\end{array}$ & Verde oscuro & $\begin{array}{l}\text { Santa María } \\
\text { la Redonda }\end{array}$ \\
\hline Berilo & $\begin{array}{l}\text { Tonos claros, verde } \\
\text { pálido, amarillo, } \\
\text { blanco }\end{array}$ & Ocre claro & $\begin{array}{l}\text { Santa Catarina } \\
\text { Mártir }\end{array}$ \\
\hline Topacio & $\begin{array}{l}\text { Brillantísimo, } \\
\text { de incoloro a } \\
\text { amarillo }\end{array}$ & Amarillo & $\begin{array}{c}\text { Santa Cruz } \\
\text { Acatlán }\end{array}$ \\
\hline Crisoprasa & $\begin{array}{l}\text { Amarillo y verde, } \\
\text { de verde medio } \\
\text { a amarillento }\end{array}$ & $\begin{array}{l}\text { Amarillo } \\
\text { verdoso }\end{array}$ & San Miguel \\
\hline Jacinto & $\begin{array}{l}\text { Azul celeste, } \\
\text { púrpura }\end{array}$ & Morado & Santo Tomás \\
\hline Amatista & Violeta rosáceo & Rosa & $\begin{array}{l}\text { San Juan de la } \\
\text { Penitencia }\end{array}$ \\
\hline
\end{tabular}

de Veracruz a Yucatán, y en el mar Caribe. ${ }^{126}$ En consecuencia, ya no a la Virgen, sino a Cristo, pudiera hacer alusión el color encarnado de la parroquia central de la capital. ${ }^{127}$ Cuando, en

126 García-Cubas y Reguero, Catálogo, p. 37.

127 "Y está vestido con un manto teñido de sangre, y su nombre es la Palabra de Dios", Apocalipsis, 19, 13. 
1772, el bachiller debió incorporar las tres nuevas vicarías que seccionaban dicho curato, utilizó tres nuevos pigmentos que no seguían la lógica anterior: dos tonos neutros, blanco y negro, y otro no uniforme, el "jaspeado", representado con motas verdes, azules, amarillas y rojas sobre fondo blanco. ${ }^{128}$ No en balde, retomando a Pastoureau, la función primaria del color es clasificar: "asociar, oponer, distinguir, jerarquizar". ${ }^{129}$

Así pues, el juego de colores planteado por Alzate desata un zozobrante proceso de significación simbólica de la ciudad. Dota de un sentido mítico y religioso que trasciende, aparentemente, los parámetros de la Ilustración pero que, en absoluto, es algo ajeno a las propias Luces. Como explicó Oncina Coves, "el propósito de integrar en un mismo destino filosofía y arcano, luz y tinieblas, publicidad y misterio", formaba parte intrínseca de las recreaciones intelectuales de los ilustrados. ${ }^{130}$ Sutilmente, la reconstrucción mexicana de la Nueva Jerusalén provee de una identidad retórica a los espacios de la ciudad. Va más allá del nuevo orden moral que plantease fray Juan de Torquemada al contrastar la capital azteca con Babilonia, "república de confusión y maldades", con la que es "ahora otra Jerusalén, madre de provincias y reinos" ${ }^{131}$ La intervención de Alzate no es evidente ni pública, decidida a autojustificarse ante una gran audiencia, sino velada y reservada a unos pocos iniciados. La propuesta de una lectura secreta de la urbe, donde el color en el mapa funciona como vehículo que informa místicamente el territorio, es una forma autocomplaciente, por parte de sus promotores, de avanzar hacia la ciudad "instaurada por el discurso utópico y urbanístico" de la que hablase Michel de Certeau. ${ }^{132}$

128 "El curato del Sagrario comprehende los Colores Blanco, Negro, Nácar y Jaspeado", margen inferior derecho del "Plano de la Ymperial México", 1772.

129 Pastoureau, Los colores, p. 244.

130 Oncina, Historia, p. 125.

131 Torquemada, Monarquia, lib. III, cap. XXVI, p. 415.

132 Certeau, La invención, p. 106. 
Así pues, esta "nueva" ciudad de México no tiene la necesidad de constituirse a sí misma, como tantas otras urbes, como "centro del mundo" en un sentido simbólico, mítico o de poder. ${ }^{133}$ En cambio, en consonancia con los fines espirituales de la reforma parroquial, transciende la territorialidad y mira, más allá, hacia un nuevo orden celestial.

\section{RESISTENCIAS Y PROPUESTAS PARA UN NUEVO MAPA}

Dos días transcurrieron desde que Alzate presentó su memoria hasta que Lorenzana la remitió al virrey Marqués de Croix, el 25 de enero de 1769, solicitando su apoyo ante el monarca. En su argumentación en favor de la reforma parroquial, el arzobispo retomó muchas de las ideas que el bachiller le había puesto por escrito. Sin titubeos, equiparó su medida con el propósito virreinal de "distribuir los quarteles de esta ciudad para [...] la justicia en cada uno de los barrios", al tiempo que refirió la incompleta secularización de los curatos como el principal escollo para su implementación. ${ }^{134}$ No obstante, Lorenzana detalló una diferencia sustancial respecto al plan recién expuesto por el presbítero: el arzobispo ahondó en las dificultades particulares de la parroquia del Sagrario, administrada por cuatro sacerdotes que se turnaban semanalmente para atender a sus fieles, y convino en que lo más oportuno sería "señalar a cada uno de los curas del Sagrario territorio, según se demuestra en el mapa adjunto, para cuyo fin conduce mucho la buena formación de calles y cuadras de esta ciudad". ${ }^{135}$ Sin embargo, en los aludidos memorial y plano de Alzate, ni se referenció ni se representó división alguna dentro del Sagrario. Por tanto, si el plano que llegó a ojos

133 Tuan, Space, pp. 149-150.

134 Carta de Lorenzana a De Croix, México, 25 de enero de 1769. AGI, $M$, 727, f. 1 r.

135 Carta de Lorenzana a De Croix, México, 25 de enero de 1769. AGI, $M$, 727, f. 2 r. 
del virrey seguía dicha descripción, bien podría haber sido un repinte sobre el ejemplar ya preparado, o bien un nuevo diseño encargado a toda prisa por decisión del arzobispo.

Si Lorenzana trató de enmendar la plana a Alzate -quien ya había mostrado ciertas reticencias a la parcelación del Sagrario por cuestiones económicas- ${ }^{136}$ y pretendió imponer su criterio, el cual, a la postre, podría dar "más proporción para hacer iglesia o asignar alguna de las que fueron de los regulares de la Compañía", algo debió ocurrir para que, por el momento, la discusión sobre la reforma se mantuviese siguiendo la hechura original de Alzate. ${ }^{137}$ Cuando la descripción del mapa fue remitida un mes más tarde al Consejo de Indias, con la recomendación y visto bueno de De Croix, no solo no se mencionó ninguna segmentación en la parroquia de la Catedral (salvo en la referida carta de Lorenzana), sino que tampoco la acompañó ningún dibujo. Ciertamente, en el ínterin de despacharse la documentación a Madrid, el virrey asumió como propio el proyecto y no ocultó cierta responsabilidad e intervención sobre el mismo. ${ }^{138} \mathrm{En}$ ese sentido, cuando a comienzos del año siguiente se reciba el plano en España, meses después de haberse remitido el texto, su imagen correspondería, en efecto, a la versión inicial que preparó el bachiller. Aquel mapa, examinado por el Consejo de Indias, también se encuentra perdido. Ni siquiera llegó al Archivo General de Indias en donde, al recibirse la documentación poco tiempo después, se glosó sobre la memoria que "no vino el plano". 139

En la explicación del plano que se manejó en la corte y que fue reproducida en la cédula de aprobación de la reforma, el

\footnotetext{
136 Alzate, “Papel”, ff. 18v.-19r.

137 Carta de Lorenzana a De Croix, México, 25 de enero de 1769. AGI, $M$, 727 , f. 2 r.

138 Carta de De Croix a Julián de Arriaga, secretario de Indias, México, 27 de febrero de 1769. AGI, $M, 727$, f. $1 \mathrm{v}$.

139 Plano y su explicación. AGI, $M, 2624$, f. 1 r.
} 
12 de marzo de 1771, la antedicha partición de la Catedral tan solo se apuntó como una posibilidad: "este curato, aun para el caso en que se señalen otras iglesias a los curas del Sagrario, queda bien proporcionado". ${ }^{140}$ No sería sino hasta una vez obtenida la aquiescencia del monarca, y con el propósito de ocupar las antiguas iglesias de los jesuitas, cuando Lorenzana retomase la cuestión de la parcelación del Sagrario con el nuevo virrey, simulando tratarse de una designación regia. A petición del arzobispo, Bucareli tramitó "los correspondientes oficios a los comisionados de San Pedro y San Pablo y San Andrés, para que entreguen a disposición de Vuestra Excelencia las iglesias de su cargo, para erigirlas en parroquias como su Majestad lo manda". ${ }^{141}$ Con todo y eso, hubo voces que se opusieron -aún dentro del cabildo catedralicio- a la fragmentación de dicha parroquia, medida que se interpretó como una acción decidida a borrar la memoria de los jesuitas y con nefastas consecuencias para el sostenimiento de los clérigos: "si esto poco se divide porque sea preciso abrir las iglesias que fueron de la Compañía, es mayor la estrechez [de] los curas, es imposible que subsistan con lo que puede contribuir el territorio que les queda". ${ }^{142}$

En el ámbito de la proyección urbanística, siempre existe cierta distancia entre la planificación y la ejecución puesto que, además de otros motivos, entre ambas fases intervienen la "reivindicación” y la "impugnación”, es decir, la contestación de

140 Plano y su explicación. AGI, $M, 2624$, f. 6r. Real cédula de 12 de marzo de 1771. AGN, $R C O$, vol. 98, exp. 56, f. 118r. Se desconoce, por tanto, la especificidad de las divisorias internas del Sagrario que, sin éxito, tanteó Lorenzana a comienzos de 1769. A pesar de la fecha dada, la real cédula no se expidió sino hasta el 26 de septiembre. Consejo de Indias de 15 de diciembre de 1777. AGI, $M, 2624$.

141 Carta de Bucareli a Lorenzana, 20 de noviembre de 1771. AGN, TC, vol. 8, exp. 4, f. 119 r.-v.

142 Testimonio de José Pereda, diciembre de 1771. AGN, TC, vol. 8, exp. 4, f. $122 \mathrm{r}$. 
los interesados y la réplica de los promotores del proyecto. ${ }^{143}$ Según Zahino, fue la prepotencia de Lorenzana la que provocó las numerosas resistencias y reacciones que se declararon contra su plan. ${ }^{144}$ Sin embargo, buena parte de los argumentos de oposición no fueron tanto contra la reforma territorial como frente a otras medidas del prelado que acabaron por confundirse como parte sustancial de la misma. Algunas de aquellas tensiones se habían fraguado tiempo atrás y otras se gestaron al momento de hacerse público el nuevo ordenamiento espacial.

Una de ellas fue el conflicto por absentismo con el sacristán mayor de la Catedral, José Antonio Pinedo, quien estaba en España y a quien Lorenzana había privado de su paga. En su trifulca con el arzobispo, Pinedo aprovechó el plan de descomposición del antiguo territorio del Sagrario y de la parroquia de San Miguel, de donde también percibía una parte de su estipendio, para justificarse como parte agravada en el conflicto. ${ }^{145}$ Habiendo contado inicialmente con el apoyo de De Croix, y tras un prolongado tira y afloja contra el prelado y su reforma parroquial, Pinedo logró la preservación de sus honorarios catedralicios pero no las obvenciones correspondientes a San Miguel. ${ }^{146}$

Por otro lado, la nueva distribución territorial chocó de frente con la cuestión de los curatos de los franciscanos -en proceso de secularización-y el destino de sus iglesias, hasta entonces cabecera de colaciones de indios. Los argumentos históricos pesaron para que el convento de San Francisco y el colegio de Santiago Thatelolco permaneciesen por derecho propio en manos de los mendicantes. En el caso de Santiago, éste quedaría libre de sus funciones parroquiales y la cabecera podría ser erigida "con gran comodidad en la hermita de Santa Ana, que es nueva", u otra

${ }^{143}$ Lefebvre, La revolución, pp. 41-42.

144 Zahino, Iglesia, p. 58.

145 El pleito de José Pinedo es analizado por Sierra, El cardenal, pp. 133-136.

146 Real cédula de 13 de agosto de 1775. AGI, M, 2624. 
capilla que se designase a tal fin. ${ }^{147}$ Respecto a San José, aunque el Consejo de Indias titubeó sobre si sería oportuno concederle a los regulares su administración parroquial, tal y como éstos deseaban, ${ }^{148}$ se interpretó la ley en su contra, pues ya habían aceptado a cambio la cesión de los curatos de Texcoco y Toluca, siendo "claro que ningún derecho les quedó en el territorio de esta parroquia". ${ }^{149}$ Encajar su jurisdicción en San Juan o en Salto del Agua -como se llegó a proponer- supondría quebrar el buen orden establecido, pues "siempre que se haga qualquiera otra extensión o variación, enteramente se desarregla la justa y arreglada distribución". ${ }^{150}$

Por su parte, los curas de la ciudad no parecían muy informados ni de las intenciones ni de las gestiones de su arzobispo. Un año antes de que Carlos III aprobase la reforma, y ajenos a todo el devenir cortesano, los párrocos de indios de San Pablo, Santa Cruz, San Sebastián y Santa María comunicaron su propia propuesta y sus deseos de ensanche territorial a partir de la secularización de San José, lo que encontraban como una "oportunísima coiuntura a formar la división territorial de parroquias, tan pretendida y necesaria $[\ldots]$ por la confusión de diversos feligreses dentro de un territorio y casa". ${ }^{151}$ Una vez recibida en México

147 Informe de Domingo de Trespalacios y Francisco Antonio de Echavarri, Madrid, 21 de septiembre de 1770. AGI, M, 727, f. 2v. Sobre la secularización de Santiago Tlatelolco, véase Álvarez-IcAZA, "La secularización”, pp. 316324. La estructura social y la adecuación de Tlatelolco en el nuevo sistema parroquial han sido analizadas recientemente por Gonzalbo, Del barrio, especialmente, pp. 35-82.

148 Consejo de Indias, 7 de diciembre de 1770. AGI, $M, 727$.

149 Por las reales cédulas de 1 de febrero de 1753 y de 23 de junio de 1757, los frailes podían conservar una o dos parroquias "de las más pingües", así como los conventos debidamente fundados donde habitaran al menos ocho religiosos.

150 Informe de Domingo de Trespalacios y Francisco Antonio de Echavarri, Madrid, 21 de septiembre de 1770. AGI, M, 727, ff. 3v.-4r.

151 Testimonio de los párrocos de Santa Cruz, San Sebastián, Santa María y San Pablo (respectivamente, Gregorio Pérez Cancio, Tomás Domingo Figueroa, 
la cédula, en noviembre de 1771, y enterados de los planes de Lorenzana, los párrocos de españoles elevaron inmediatamente una protesta al rey expresando su malestar por la medida recién decretada: "se trata de dividirles los territorios, de añadirles nuevas cargas, y de mudar enteramente la substancia y aspecto de los beneficios". ${ }^{152}$ Consideraron que el proceder del prelado, "con tanto sigilo", no solo había sido contrario a derecho sino ejecutado con malas artes, pues había condicionado la decisión real "por influxo de unos informes equívocos y agenos de lo que pasa en estas parroquias", ${ }^{153}$ criticando injustamente la labor de los sacerdotes y sin darles ni voz ni voto en todo el proceso: "no se ha citado ni oydo a los actuales curas, sin su consentimiento, y sin ciencia de ellos, se quiere poner en práctica y sin admitirles las excepciones más legitimas se quiere executar". ${ }^{154}$ Sin ningún éxito y con pobres argumentos, en su "difusa representación” 155 los párrocos de españoles pretendieron incluso restaurar la consabida división étnica. ${ }^{156}$

Ante semejante contestación, y deseoso de dejar afianzada su reforma antes de partir a España, a donde había sido llamado

José Serrano y Juan José Pina), 16 de mayo de 1770. AGN, TC, vol. 8, exp. 4, f. 108r. Generalmente, esta correspondencia ha sido interpretada en clave de oposición al plan de Alzate, sin que parezca probado que los párrocos tuvieran noticias de dicho proyecto. Antes bien, esta memoria se planteó para corregir y fraccionar el curato de San José, recientemente secularizado. Pescador, De bautizados, pp. 31-32; DÁvalos, Los letrados, p. 57; O’Hara, A Flock, pp. 128-130.

152 Protesta de los curas de españoles al rey, 10 de noviembre de 1771. AGI, $M, 2659$, f. 2v. Estos fueron los cuatro de la Catedral (Nuño Núñez de Villavicencio, José Pereda, Alonso Velázquez Gastelu y Juan Francisco Domínguez); el párroco de San Miguel, Bartolomé Sandoval; Joaquín del Pino, de Santa Catarina; y José Tirso Díaz, de la Santa Veracruz.

153 Protesta de los curas de españoles al rey. AGI, $M, 2659$, f. $1 \mathrm{v}$.

154 Protesta de los curas de españoles al rey. AGI, $M$, 2659, f. 3 r.

155 Respuesta del fiscal del Consejo de Indias a los curas de españoles, 12 de febrero de 1772. AGI, $M, 2659,1$ r.

156 ZaHino, Iglesia, pp. 59-60. 
como arzobispo primado el 2 de agosto, Lorenzana citó a "todos los curas párrocos propietarios e interinos de esta ciudad para que en el día lunes dos del próximo mes de diciembre, se junten ante Nos en nuestro palacio". ${ }^{157}$ Más que como una concesión del prelado, los capitulares interpretaron "ser de su obligación convocar" a los sacerdotes "y conferir con ellos". ${ }^{158}$ Pues el asunto se habría resuelto mejor "si al principio de este negocio, antes de presentarse el primer mapa de división de curatos y asignación de nuevos territorios, [el arzobispo] se hubiese dignado hazer derechamente alguna insinuación al cabildo". ${ }^{159}$

El propósito conciliador de aquella reunión, y las que siguieron los días 6 y 14 de diciembre, era "tratar conferir y determinar de acuerdo lo que sea más conveniente para que se verifique lo mandado" en la real cédula. ${ }^{160}$ Las juntas se hicieron "teniendo presente el plano o mapa aprovado por Su Majestad" y referenciando continuamente sobre él los problemas espaciales derivados de la nueva división. ${ }^{161}$ A pesar de la "paz, armonía y mutuo consentimiento" con que Lorenzana valoró el transcurso de las asambleas, ${ }^{162}$ no demasiado bien debió de terminar la primera de aquellas cuando, incomodado, el cura del Sagrario José Pereda aseveró que "la insinuación que vuestra excelencia ilustrísima me hizo al salir de la junta me pone la pluma en la mano para representar por escrito lo mismo que apuntaba de

157 Lorenzana a los párrocos de la ciudad, 29 de noviembre de 1771. AGN, TC, vol. 8, exp. 4, ff. 119v.-120r.

${ }^{158}$ Copia del parecer del señor doctoral sobre la división de parroquias, 11 de enero de 1772. ACM, $A C$, vol. 51, f. 151v.

${ }^{159}$ Copia del parecer del señor doctoral sobre la división de parroquias. ACM, $A C$, vol. 51, f. 152 r.

160 Lorenzana a los párrocos de la ciudad, 29 de noviembre de 1771. AGN, TC, vol. 8, exp. 4, f. 120 .

${ }_{161}$ Reunión de Lorenzana con los párrocos de la ciudad, 14 de diciembre de 1771. AGN, TC, vol. 8, exp. 4, f. 126r.

162 Copia del billete de Lorenzana sobre división de parroquias, 23 de diciembre de 1771. ACM, $A C$, vol. 51, f. 145v. 
palabra”. ${ }^{163}$ En términos duros, pero juzgándose a sí mismo como un "hombre desapasionado o imparcial" -puesto que anunciaba su pronta renuncia al cargo ostentado-, Pereda explicó las "muchas de las dificultades" económicas y pastorales que se derivarían de la nueva división, la cual tildó de "rigurosa y formal enajenación”. ${ }^{164}$ En lo que respecta al territorio, el alegato del sacerdote determinó en gran medida las modificaciones que adoptase Lorenzana, quien consideró sus argumentos en posteriores reuniones. ${ }^{165}$ Pereda había señalado cómo los confines del Sagrario con las parroquias de San Miguel y San Sebastián constituían un obstáculo a la pretendida fragmentación del curato catedralicio, pues era incomparable el aporte económico de la población española que se perdía con la contribución de los indios que se agregaban. Respecto al margen meridional, explicaba cómo

[...] la división, si se verifica conforme al mapa, quita al Sagrario quasi la mitad de feligreses que oy tiene, porque del quarto que corre desde la esquina del Portal de los Mercaderes al Sur apenas le quedan dos calles, y del otro cuarto que llamamos de Palacio le queda este, que es de sumo trabajo por la Carcel de Corte y mui pequeña parte de oriente, y en esta entra la Ysleta de Jesús María totalmente inútil para la parroquia. ${ }^{166}$

Según el criterio de Pereda, tal y como estaba el diseñado plan, y “en el supuesto de que pueda verificarse la división”, solo

163 Testimonio de José Pereda, diciembre de 1771. AGN, TC, vol. 8, exp. 4, f. 120 r.

164 Testimonio de José Pereda. AGN, TC, vol. 8, exp. 4, f. 123r. Sobre el informe de Pereda, véase SIERra, El cardenal, pp. 141-143.

${ }^{165}$ Reunión de Lorenzana con los párrocos de la ciudad. AGN, TC, vol. 8, exp. 4 , f. 125 r.

166 Testimonio de José Pereda, diciembre de 1771. AGN, TC, vol. 8, exp. 4, f. $120 \mathrm{v}$. 
podrían mantenerse dos vicarías en el ámbito de la catedral. No obstante, "si la línea divisoria del sur se retira un poco estrechando el curato de San Miguel, podrán quedar tres con los vicarios respectivos que son siempre necesarios, porque la gente ha de acudir siempre al Sagrario por la maior comodidad". ${ }^{167}$ Valorando esto, Lorenzana propondrá a los sacerdotes una nueva división para San Miguel, que sería aprobada el 14 de diciembre. Dicha parroquia perdía su mitad oeste, ámbito que se agregaba al Sagrario y en el que se estableció la mayor parte de la nueva vicaría dedicada al santo mexicano Felipe de Jesús, que reemplazaba a la advocación de San Felipe Neri, en la antigua iglesia del Oratorio. ${ }^{168}$ Hacia el norte, sin embargo, se compensaba esta pérdida con la anexión de una hilera de manzanas más próxima a la Catedral (mapa 7). Aunque sería administrada de manera independiente, para ayudar a su sostenimiento y por su antiguo vínculo con la Catedral, el prelado planteó crear "una masa común de los derechos y emolumentos que producen uno y otro beneficio y se parta por iguales partes entre los tres párrocos del Sagrario y el de San Miguel", además de cederle la octava de las obvenciones que históricamente percibían los prelados, medidas que pugnarían el referido sacristán Pinedo y el cabildo catedralicio. ${ }^{169}$

Por otro lado, respecto al extremo opuesto de la jurisdicción del Sagrario, argumentó Pereda que,

167 Testimonio de José Pereda, diciembre de 1771. AGN, TC, vol. 8, exp. 4, f. 122 r.

168 En opinión de Lorenzana, San Felipe de Jesús cumpliría buenas funciones como parroquia, pues "luego que se acave es la más proporcionada para poderla eregir en curato, porque es la parte de México en que más se necesita". Copia del billete de Lorenzana sobre división de parroquias. ACM, $A C$, vol. 51, f. 146r. Los religiosos del Oratorio o filipenses fueron reubicados en la iglesia jesuita de La Profesa.

169 Reunión de Lorenzana con los párrocos de la ciudad. AGN, TC, vol. 8, exp. 4, f. 127r. Esta cesión de la octava será litigada por el cabildo catedralicio. Copia de la respuesta que dio el cabildo al virrey sobre la división de parroquias, 11 de enero de 1772. ACM, $A C$, vol. 51, f. 143r.-v. 


\section{Mapa 7}

DETALLE DEL CURATO DE SAN MIGUEL EN EL

“PLANO DE LA YMPERIAL MÉXICO”. EN PUNTEADO SE SEÑALA

LA DEMARCACIÓN DE 1769, Y SOMBREADA LA DE 1772

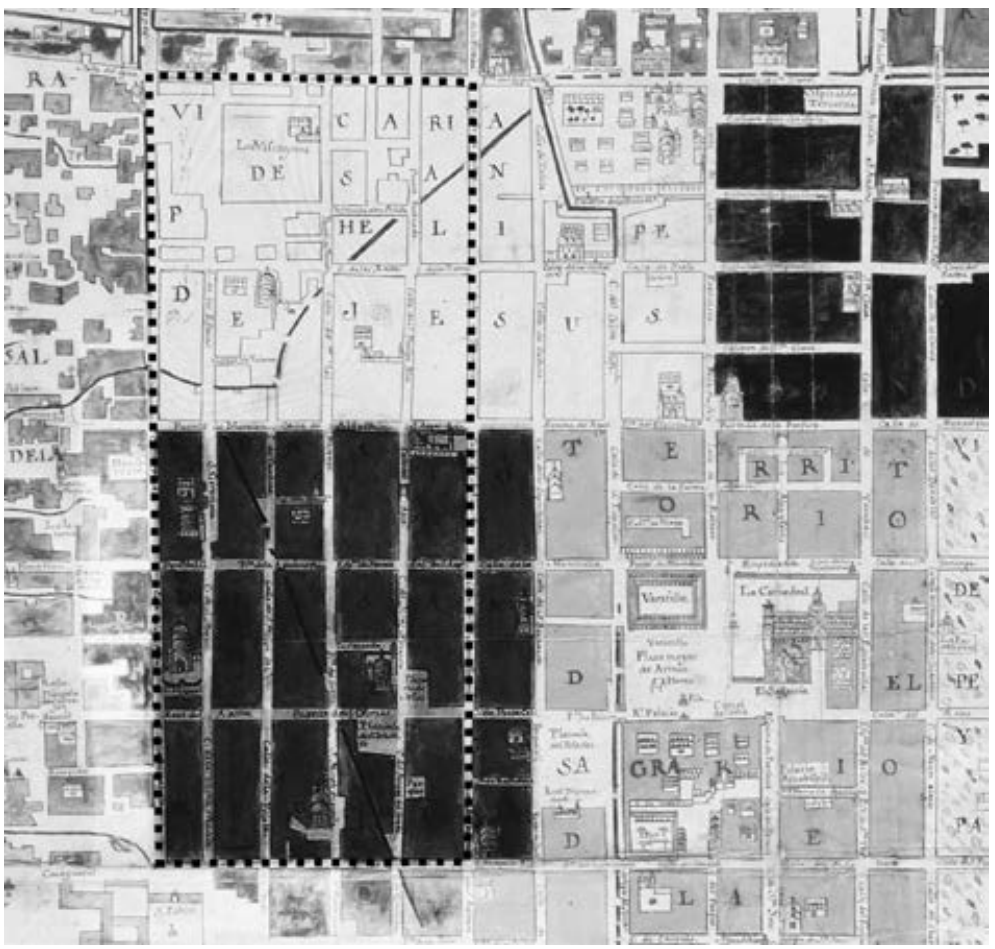

[...] por el oriente se le quita hasta el puente de la Leña y colegio de Nuestro Padre San Pedro, todo el barrio de San Sebastián hasta la calle del Carmen, las de Arcinas y Moras, de suerte que si con vista de los padrones se hace la cuenta tengo por cierto que resultará acaso que la dismembración excede de la mitad de la feligresía. ${ }^{170}$

170 Testimonio de José Pereda, diciembre de 1771. AGN, TC, vol. 8, exp. 4, ff. $120 \mathrm{v} .-121 \mathrm{r}$. 
Y así, siguiendo su consejo, Lorenzana, decidido "a proporcionar la más fácil y conveniente división de territorios parroquiales", volvería a rectificar las lindes dispuestas por Alzate y sancionadas por el rey. El Sagrario incrementaría su territorio sumándose el espacio comprendido desde la calle del Hospicio de San Nicolás hasta abarcar la cuadra contenida por la iglesia de San Pedro y San Pablo, que sería cabecera de la vicaría del mismo nombre, al tiempo que cedía a San Sebastián dos manzanas al poniente, entre las calles Arcinas y Cerbatana (mapa 8). Compensando la mengua territorial de dicho curato, en la junta con los párrocos se decidió agregarle "el rancho de Pacheco, llamado de Ortega". ${ }^{171}$ Situado más allá del albarradón, sus vecinos -mayoritariamente indiosvivían no sin conflictos de la explotación de los recursos y pastos lacustres, considerados bienes comunales. ${ }^{172}$ Quedando fuera del espacio dibujado por José Antonio de Alzate en el "Plano de la Ymperial México", junto a la demarcación del "Oriente”, una recta señaló el rumbo donde éste se encontraba: "En la dirección de la línea C. D. se halla el Rancho de Ortega, o de Pacheco, debe corresponder al Curato de San Sebastián”.

Además de dichos cambios, el 14 de diciembre de 1771 se formalizaron "de común acuerdo" otras modificaciones sobre el plano de Alzate. El territorio del Sagrario quedó compartido con tres vicarías auxiliares, fijándose las cuadras correspondientes a San Pedro y San Pablo, San Felipe de Jesús y San Andrés. ${ }^{173}$ Y como medida que favoreciese su financiación, se decidió suprimir la provisión y el título de la primera vacante que resultase, por muerte o renuncia, entre los curas de la Catedral. ${ }^{174}$ Así

171 Reunión de Lorenzana con los párrocos de la ciudad. AGN, TC, vol. 8, exp. 4, f. 132 r.

172 DÁvalos, Los letrados, pp. 79-98.

173 Reunión de Lorenzana con los párrocos de la ciudad. AGN, TC, vol. 8, exp. 4, ff. 129r.-130r.

${ }_{174}$ Copia del billete de Lorenzana sobre división de parroquias, 23 de diciembre de 1771. ACM, $A C$, vol. 51, f. 146r. 


\section{Mapa 8}

DETALLE DEL CURATO DE SAN SEBASTIÁN EN EL “PLANO DE LA YMPERIAL MÉXICO”. EN PUNTEADO SE SEÑALA LA DEMARCACIÓN DE 1769 Y SOMBREADA LA DE 1772

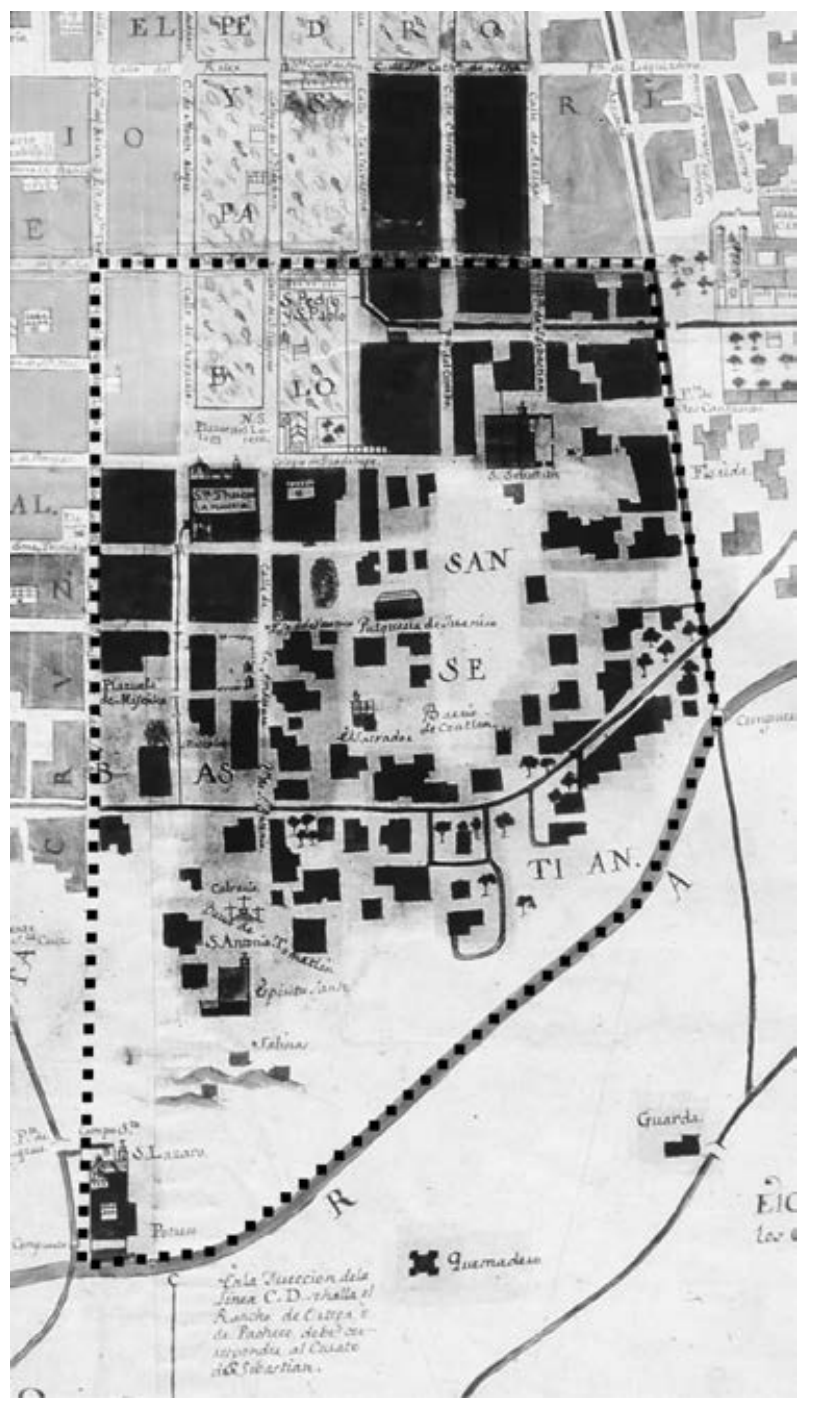


mismo, se establecieron las iglesias cabecera en las parroquias de San Pablo, "por ahora en la capilla de San Lucas”, y Santiago Tlatelolco, donde “se pondrá en la capilla de Santa Ana”. ${ }^{175}$ Un cambio sustancial era el del referido "curato que según el primer mapa y citada real cédula se debía nombrar de San Juan de la Penitencia”, ${ }^{176}$ que -obedeciendo al Consejo de Indias, pero arguyendo motivos territoriales- recuperó el título de San José y su primitiva capilla como sede,

[...] en atención a estar fundada en ella una cofradía de españoles, a que hallándose como se halla en una plazuela, está proporcionada para que pueda dársele la necesaria extensión, lo que no se verifica en la de San Antonio de los Callejones por falta de terreno e igualmente para que conserve el nombre y advocación que tenía antes de secularizarse. ${ }^{177}$

A la parroquia de la Santa Veracruz se le sumó la ayuda de San Antonio de las Huertas, colación que años más tarde sería separada, ${ }^{178}$ pero que por su distancia Alzate nunca consideró como parte de las parroquias de la ciudad. ${ }^{179}$ A Santa Cruz se le añadió el curato del Peñol de los Baños, sobre el

175 Reunión de Lorenzana con los párrocos de la ciudad. AGN, TC, vol. 8, exp. 4, ff. 132v. y $133 \mathrm{v}$.

176 Copia del parecer del señor doctoral sobre la división de parroquias. ACM, $A C$, vol. 51, f. 151v.

177 Reunión de Lorenzana con los párrocos de la ciudad. AGN, TC, vol. 8, exp. 4 , f. $127 \mathrm{v}$.

${ }_{178}$ A pesar de localizarse fuera de la ciudad, por su antiguo vínculo urbano como ayuda del secularizado curato de San José, a posteriori y a efectos prácticos, en numerosas ocasiones se sumó en la nómina de las parroquias de la capital. Aunque Moreno DE LOS Arcos, “Los territorios”, p. 15, señaló fehacientemente como 13 el número de parroquias resultantes de la reforma, la historiografía suele repetir la cifra de 14, por lo general, por contar erróneamente la de San Antonio de las Huertas.

179 "Es notorio que las parroquias de México son 13: digo que son trece porque no debe incluirse la de San Antonio de las Huertas.” Representación de 
que Alzate apuntó en los márgenes de su "Plano de la Ymperial México" que "pertenese a Santa Cruz pues se halla en su misma dirección”. También se sumaron a esta parroquia los ranchos de Pacheco, "nombrado de Balbuena", y el del Tesoro, a pesar de estar más próximos al curato de Santo Tomás. ${ }^{180} \mathrm{Tal}$ y como explicó el presbítero en el extremo inferior del plano de 1772, señalando su situación con una raya, la continuidad y comunicación interna de los ámbitos parroquiales era una de las premisas que guiaba el proyecto: "En la dirección de la línea A. B. se hallan los Ranchos de Pacheco que lla[ma]n de Barbuena, y Thesoro, debían pertecer a Santo Thomás, pero como no tienen más comunicasión que por el Guarda de San Lázaro, y este se halla en el Territorio de Santa Cruz, se han asignado a este curato".

Obtenido el voto favorable de la mayoría de los párrocos, Lorenzana comunicó al virrey Bucareli las modificaciones acordadas, a fin de que las pasase al fiscal y a los cabildos eclesiástico y secular "para que se apruebe y finalice con el consentimiento de todos". Probablemente, las acompañase con el último mapa que Alzate habría ejecutado por orden del arzobispo, una representación con "la forma que verá vuestra excelencia por el instrumento adjunto". ${ }^{181}$ No obstante, si alguna vez aquel plano fue a parar a manos de Bucareli, no llegó sin embargo a ojos de los sacerdotes capitulares, quienes aprovecharon la ausencia de una imagen para-sin éxito alguno-retorcer la descripción de las divisorias, generando confusión en el diseño de la ciudad. Por un lado, reprocharon que "en la Plazuela de la Santísima Trinidad [coinciden] feligreses de tres parroquias, la Cathedral, Santa

\footnotetext{
Alzate al virrey Revillagigedo, 10 de marzo de 1791. AGN, $H$, vol. 74, exp. 1, f. 10 r.-v.

180 Reunión de Lorenzana con los párrocos de la ciudad. AGN, TC, vol. 8, exp. 4, ff. 131v.-132r.

${ }^{181}$ Copia del billete de Lorenzana sobre división de parroquias. ACM, $A C$, vol. 51, f. 146r.
} 
Cruz y San Sebastián”. Y, por otro, se mintió al afirmar cómo "la Puente del Zacate sirve de división a quatro parroquias, de la Cathedral, Santa Veracruz, Santa Cathalina Mártir y Santa María la Redonda". ${ }^{182}$ La crítica era infundada pues, desde el primer proyecto, se habían mantenido estables los límites de Santa María: su borde meridional era la acequia que pasaba por el puente del Zacate hasta el de la Misericordia, coincidiendo en aquel punto únicamente con las colaciones de la Veracruz y la Catedral (mapa 9). Sin mayores réplicas que la defensa de sus derechos económicos, los capitulares claudicaron, no sin dejar constancia de que tal consulta había sido una pantomima: "ni que parece mira este oficio a otra cosa que a una pura noticia de esta novedad". ${ }^{183}$

Finalmente, esperando su aprobación antes de la partida de Lorenzana, el fiscal José Antonio de Areche manifestó ante el virrey la necesidad de ratificar el proyecto resultado de las recientes conversaciones del arzobispo, "porque ve que el segundo plan de división se formó con acuerdo y anuencia de todos los curas interesados" y había logrado el beneplácito de los cabildos civil y eclesiástico. ${ }^{184} \mathrm{El}$ ayuntamiento se había mostrado favorable a la nueva estructuración, deseando que las previsiones económicas fuesen las más adecuadas "para que todo se perfeccione sin gravamen del público". ${ }^{185}$ Tras el inmediato consentimiento de Bucareli, como vicepatrono de la Iglesia, Lorenzana decretó fijar en un edicto la división parroquial definitiva. No obstante, quedaría en suspenso la referida cesión de la octava del Sagrario a las vicarías y a la parroquia de San Miguel, hasta que el Consejo de Indias resolviese los pleitos

182 Acta del cabildo de 10 de enero de 1772. ACM, $A C$, vol. 51, f. 153r.

183 Acta del cabildo de 10 de enero de 1772. ACM, $A C$, vol. 51, f. 153 r.

184 Testimonio de la representación del fiscal Areche al virrey Bucareli, 25 de febrero de 1772. AGI, $M, 2624$, f. $24 \mathrm{v}$.

185 Testimonio del cabildo de la nobilísima Ciudad de México al virrey, 19 de febrero de 1772. AGI, $M, 2624$, f. $22 \mathrm{v}$. 


\section{Mapa 9}

DETALLE DE LOS LÍMITES DE SANTA MARÍA EN EL “PLANO DE LA YMPERIAL MÉXICO”

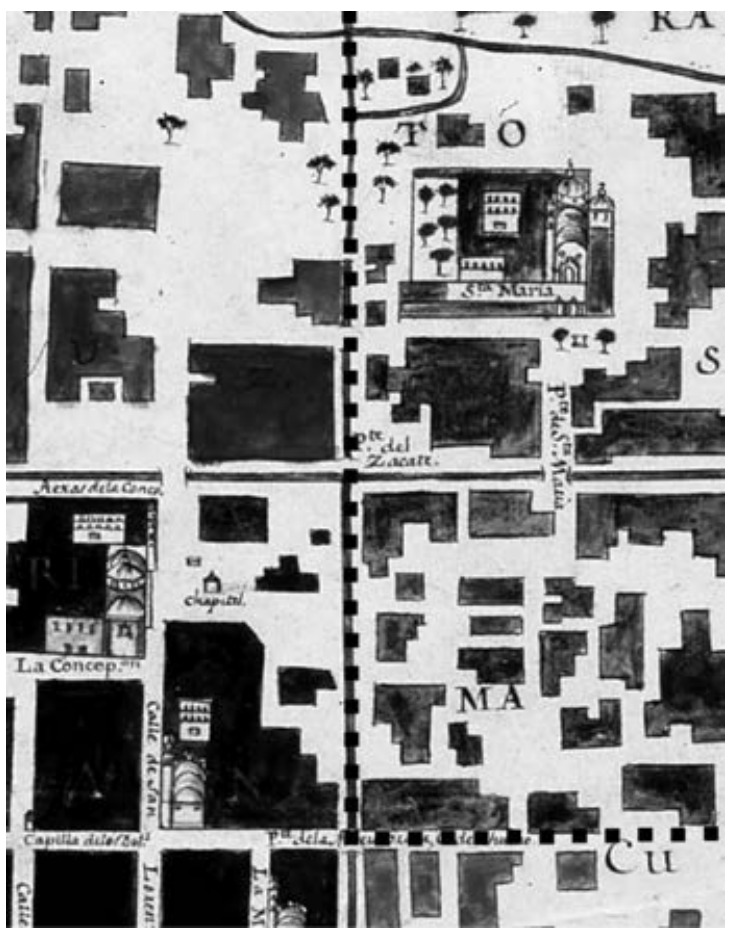

abiertos. ${ }^{186}$ Junto con el texto de aprobación de las nuevas divisorias, el arzobispo mandó proveer de una imagen cartográfica de su respectivo curato a cada uno de los párrocos de la ciudad:

Entréguese un exemplar de este [edicto] a cada párroco, con un mapa, o plano del territorio, que a cada parroquia pertenece, fielmente sacado del general que obra con estas diligencias, y certificado

186 Billete con la aprobación de la reforma parroquial de Lorenzana, 2 de marzo de 1772. AGI, $M, 2624$, f. 26 r. 
en forma, y evaquadas todas las demás, pásese testimonio de ellas a la secretaria del excelentísimo señor virrey para su constancia. ${ }^{187}$

Aunque no se conoce ninguno de estos ejemplares, los planos individuales de las parroquias fueron elaborados y costeados por José Antonio de Alzate a partir de su mapa más reciente, según él mismo aseguró. ${ }^{188}$ Es muy posible que tales cartografías particulares guardasen gran semejanza con el aspecto del “Territorio del Curato de San Pablo de la Ciudad de México" (mapa 10) ${ }^{189}$ que, a su vez, es prácticamente similar en diseño, detalles y contenido al "Plano de la Ymperial México" y muestra, además, la característica franja roja que enmarca la mayoría de los diseños de Alzate. Tanto aquel mapa general referido por el arzobispo como los específicos de los curatos adquirieron inmediatamente un carácter oficial, tal y como explicita el reverso del citado dibujo de San Pablo, enviado al Consejo de Indias hacia 1781, como parte del expediente sobre los problemas acarreados tras su secularización: ${ }^{190}$

Certifico en forma y doy fe, que este plano corresponde en todo a lo resuelto en los autos fechos sobre la división de parroquias y asignación de sus territorios de esta Ciudad de México, con acuerdo, y formal consentimiento del excelentísimo señor virrey, gobernador, capitán general y vicepatrono de este reyno de Nueva España, y está bien y fielmente copiado por el mapa general que obra en ellos a que me refiero, como también del particular de la parroquia de San

187 Billete con la aprobación de la reforma parroquial de Lorenzana. AGI, $M$, 2624, f. 26r.

188 "Memorias, servicios y obras...”, AGI, $M, 1883$, f. 2r. Transcrito por Moreno de los Arcos en Alzate, Memorias, p. 144.

189 “Territorio del Curato de San Pablo de la Ciudad de México”, c. 1781. AGI, $M P, M, 705$.

190 Expediente sobre la secularización del curato de San Pablo. AGI, M, 2637.

O’Hara, A Flock, pp. 108-111. 


\section{Mapa 10 \\ “TERRITORIO DEL CURATO DE SAN PABLO DE LA CIUDAD DE MÉXICO”}

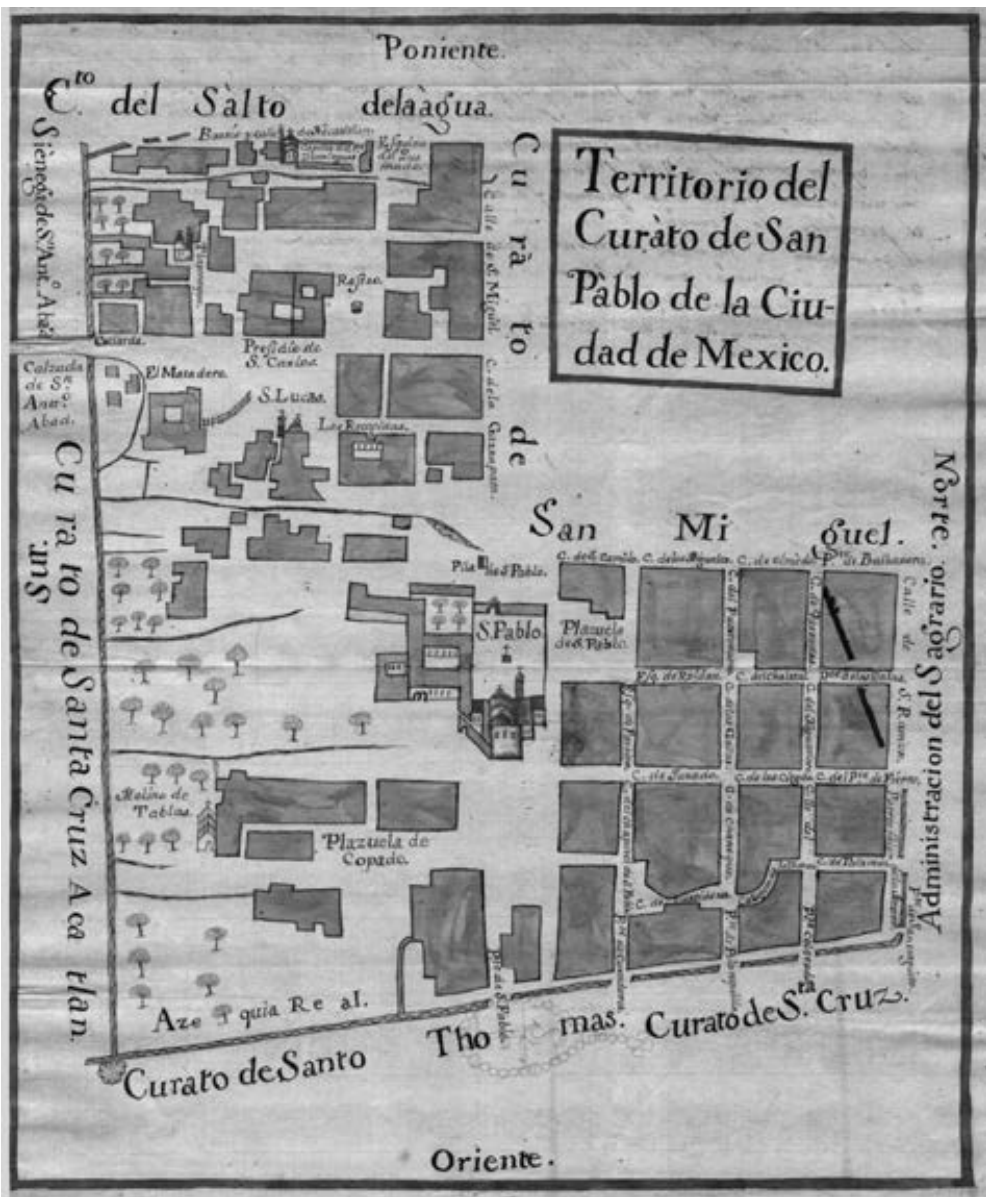


Pablo, con el que así mismo está identificado y en él demarcado su respectivo territorio parroquial. ${ }^{191}$

\section{A MODO DE SÍNTESIS}

Apenas cuatro días antes de firmar su carta de despedida como arzobispo de México, Francisco Antonio Lorenzana despachó el edicto con la nueva división parroquial, el 3 de marzo de 1772. ${ }^{192}$ Aquella reestructuración, aunque seguía en esencia el primer diseño de Alzate aprobado por el rey, incorporaba las modificaciones consensuadas a posteriori con el cuerpo de los sacerdotes de la ciudad, fundamentalmente, respecto a las lindes de San Miguel y San Sebastián con la Catedral, y la supresión del título de San Juan de la Penitencia en beneficio del de San José. El ordenamiento, con 13 parroquias y tres vicarías auxiliares del Sagrario, entraría en vigor el domingo inmediato, 8 de marzo, primero de cuaresma, a partir de cuando los curas iniciarían los nuevos padrones de feligreses. Ante todo, Lorenzana se congratulaba por culminar aquella reforma y lograr la agrupación de fieles de distintas calidades en una misma colación, llegando a equipararse a los obispos de Roma, quienes sobrepusieron la organización parroquial de la urbe a la división tribal de los latinos. ${ }^{193}$

Tras el análisis del proceso cartográfico, es posible aclarar ciertas confusiones historiográficas, que el propio José Antonio de Alzate propició, en torno de su papel en la reforma parroquial. Queda claro cómo el "Plano de la Ymperial México” no representa su proyecto de 1769 , sino el del citado edicto.

191 Certificación de Manuel Flores, secretario del arzobispo Núñez de Haro, México, 26 de junio de 1781. Reverso del “Territorio del Curato de San Pablo de la Ciudad de México”. AGI, MP, M, 705.

192 Copia de la carta de despedida de Lorenzana, 7 de marzo de 1772. ACM, $A C$, vol. 51, f. 172r.-v.

193 Edicto del arzobispo Lorenzana. AGN, B, 587, vol. 8, n. 78. 
Aunque, en lo sustancial, tan solo "se varía el territorio asignado en la primera distribución y se conserva el número de 13 iglesias parroquiales", ${ }^{194}$ aquellos cambios no debieron agradar al genio de Ozumba. Y así, al igual que en posteriores escritos el bachiller reconstruyó su mérito y protagonismo en la concepción de la reforma, ${ }^{195}$ es posible que, al mantener la fecha de 1769 sobre el "Plano de la Ymperial México", desplegase ya ciertos mecanismos de ocultación sobre las discusiones que le enmendaron la plana. De modo que, en el mapa que envió en 1772 a la secretaría del virrey, cumpliendo la orden del arzobispo, ${ }^{196}$ identificó la imagen final con su proyecto inicial, ${ }^{197}$ pues, a fin de cuentas, Alzate había mantenido una planimetría base, a partir de la cual sacó copias y presentó los diversos ensayos de su frustrado plan.

Mientras que, por un lado -cuando le interesó- Alzate reforzó su autoría sobre el proyecto, por otro, dejó constancia de cierto arrepentimiento y de los pesares que le había ocasionado obedecer a su obispo. Según afirmó, no solo no había recibido contribución alguna por su trabajo, ${ }^{198}$ sino que además le acarreó "por parte de muchos párrocos, como de los parroquianos, mucha incomodidad que aún sufro". Cuando, en la década de los noventa, el virrey Revillagigedo le encomendase elaborar un padrón de la ciudad, un anciano Alzate temerá volver a padecer "lo que he tenido que sufrir":

${ }_{194}$ Copia del parecer del señor doctoral sobre la división de parroquias. ACM, $A C$, vol. 51, f. $151 \mathrm{v}$.

195 "Memorias, servicios y obras...", AGI, $M$, 1883, f. 2r. Transcrito por Moreno de los Arcos en Alzate, Memorias, pp. 143-144.

${ }^{196}$ Billete con la aprobación de la reforma parroquial de Lorenzana. AGI, $M$, 2624, f. 26r.

197 Con la misma ambigüedad expresó a Revillagigedo la vigencia de su plan que "se aprobó por el Supremo Consejo". Representación de Alzate al virrey segundo Conde de Revillagigedo, 14 de marzo de 1791. AGN, H, vol. 74, exp. 1, f. $16 \mathrm{v}$.

198 “Memorias, servicios y obras...”, AGI, $M$, 1883, f. 2r. Transcrito por Moreno de los Arcos en Alzate, Memorias, p. 143. 
Ni el poder de vuestra excelencia ni mi sumisión sincera me pondrían a cubierto de la murmuración ni de los demás epítetos con que se me trataría: quiero dar un paso de este valle de miserias a el de la eternidad sin dejar reato por donde se me indique (aunque sin fundamento) como a perturbador de la pública tranquilidad. ${ }^{199}$

Desde su horizonte ilustrado y como estrategia para la consolidación de una nueva y perdurable fisionomía sociorreligiosa de la ciudad, los promotores de la reforma orientaron su actuación en dos niveles de intervención, uno discursivo y otro visual. Como se ha explicado en estas páginas, la transformación parroquial ni se implementó como un plan compacto y sin fisuras ni se impuso radicalmente desde arriba hacia abajo, tal y como lo presentaron Lorenzana y Alzate ante sus coetáneos. Antes bien, el definitivo modelo territorial resultó de un proceso de negociación y de cesión que fue silenciado por sus artífices y por sus sucesores, condicionando el conocimiento de la reforma hasta el presente.

Si mediante pactos, más o menos consensuados, podrían ser aceptados puntualmente los cambios por los agentes directamente implicados (como eran los párrocos), sin embargo, la permanencia y la aceptación de estas modificaciones por la colectividad y en el largo plazo dependía, en buena medida, del recurso a la autoridad como fuente de la norma. Así pues, si ya en su momento, se les ocultó a los curas la tramoya del proyecto, lo que explica -por ejemplo- la disonancia de sus memoriales acerca de la parroquia de San José (otrora interpretados como una crítica a las modificaciones territoriales del arzobispo y no como una sugerencia propositiva), también se disimuló la "forzosa” enmienda a la real cédula de Carlos III cuando, años después, Alzate se vanaglorió de la pervivencia de "su"

199 Representación de Alzate a Revillagigedo, 18 de junio de 1792. AGN, H, vol. 74, exp. 1, f. 108r.-v. 
plan. ${ }^{200}$ En este sentido, marchado ya Lorenzana, las autoridades eclesiásticas discursivamente siguieron evocando el edicto del prelado de 1772 como carta de naturaleza de la distribución parroquial que hubiere en aquel momento, a pesar de los progresivos cambios que, con posterioridad, se fueron practicando sobre la idea original.

La reminiscencia de una distribución territorial hecha por Lorenzana se consagró como justificación de cualquier nuevo orden o, mejor dicho, de toda actualización de la forma oficial, aun no correspondiéndose a la letra con la norma. Así ocurre, por ejemplo, en el repinte de las divisorias parroquiales agregado sobre un plano impreso de 1778, probablemente ejecutado en la década de los ochenta del mismo siglo (mapa 11). ${ }^{201}$ En la adenda manuscrita se afirma que "por edicto del Ilmo. S. D. Francisco Lorenzana, arzobispo de México, publicado en 3 de marzo de 1772, se señaló el territorio a los 14 curatos de esta ciudad según se ven divididos", en lugar de los 13 que verdaderamente se fijaron. Distanciándose del referido texto del arzobispo, en la imagen no solo no se señalan las tres vicarías del Sagrario sino

200 Representación de Alzate al virrey segundo Conde de Revillagigedo, 14 de marzo de 1791. AGN, $H$, vol. 74, exp. 1, f. 16v.

201 Sobre el "Plano de la nobilísima ciudad de México. Formado por el Alférez D. Ildefonso Iniesta Vejarano, Alarife Mayor de ella, Maestro del Real Desagüe, Veedor en el Arte de Arquitectura y Agrimensor más antiguo de la Real Audiencia de esta Nueva España" (también titulado en una cartela interior como "México Tenuxtitlan, ciudad de la América la más hermosa y rica, asiento de los exmos. sres. virreyes de esta Nueva España"), grabado por Manuel Villavicencio en 1778; una mano anónima señaló y coloreó las parroquias de la ciudad. El diseño mide 51 x $57 \mathrm{~cm}$ y se custodia en la LC, GM, G4414. M6 1778. I6 Vault. La doctora Barbara Mundy, de la Fordham University, ha tenido la generosidad de facilitarme la referencia e imagen de este plano que encontró en la Library of Congress, así como sus observaciones personales al respecto. De igual forma, Mary Elizabeth Haude, Senior Paper Conservator de dicha biblioteca, me ha facilitado la información catalográfica necesaria para completar esta nota. Quede constancia de mi más profundo reconocimiento y agradecimiento a ambas investigadoras. 


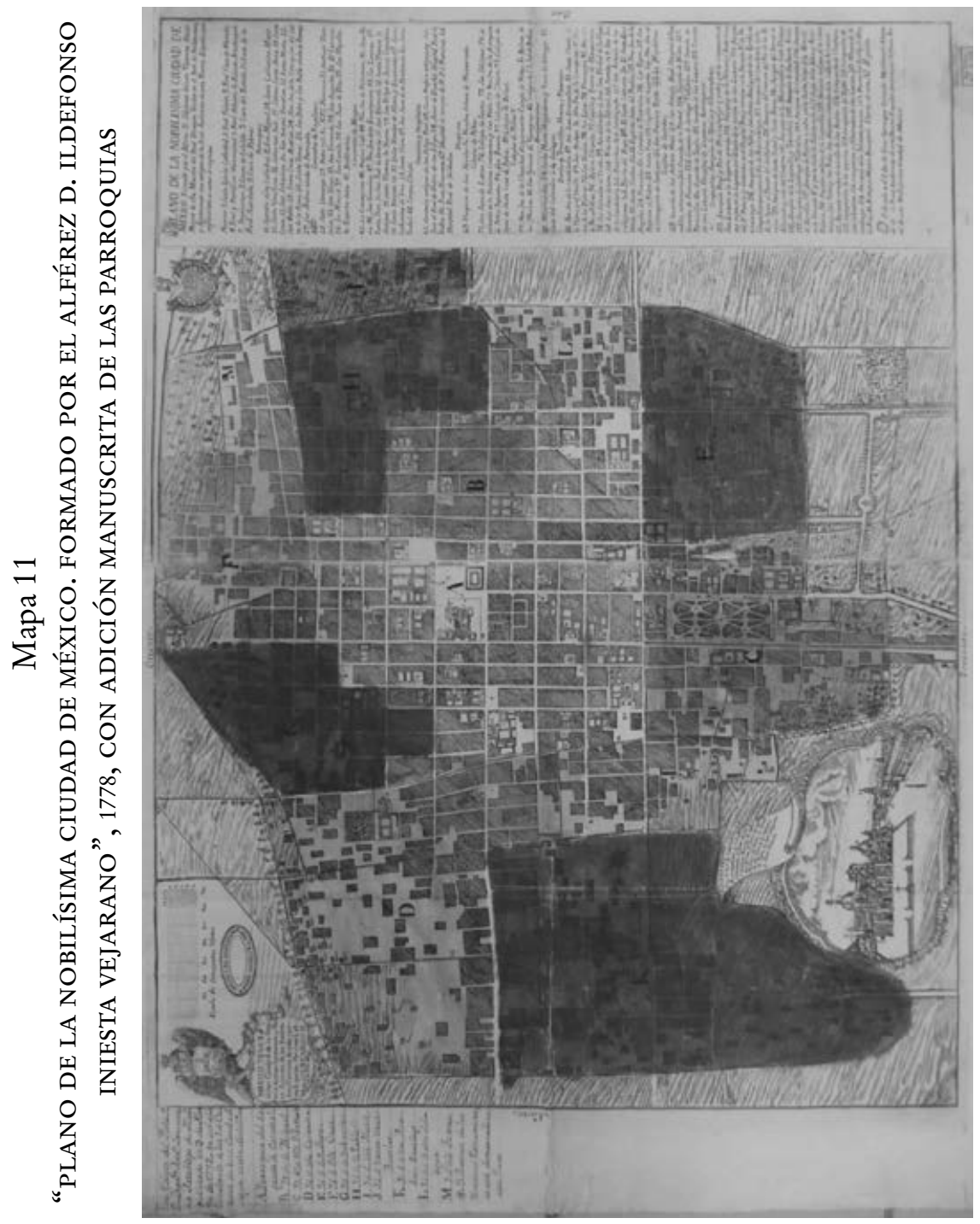


que, con un asterisco, se adicionó la parroquia de San Antonio de las Huertas, "extramuros [que] no está demarcada en este plano", a la que ya hemos hecho alusión.

El segundo nivel de intervención se sustentó en la capacidad de los artífices de la reforma para construir un decidido alegato visual para la defensa y argumentación del proyecto. Inicialmente, Alzate y, a la zaga, Lorenzana propiciaron los debates frente al plano de la ciudad y, homologando realidad y representación, desplazaron los puntos de la discusión hacia cuestiones "visibles" en el diseño preparado por el bachiller. Desde los primeros tanteos, las ideas de transformación de la urbe se recrearon y expresaron sobre un soporte cartográfico, aludiendo constantemente a una imagen mental o gráfica de la ciudad. Los problemas, debates y proyectos tomaron cuerpo concreto en la demostración visual, determinando, de este modo, un juicio estético sobre el plano, reconocido como la verdadera imagen de la urbe. Prácticamente fuera de tiempo y de sus posibilidades, la propuesta original de Alzate constituía un verdadero plan de reurbanización de la ciudad: más allá de la redistribución parroquial, entre sus aspiraciones se contaba el reacomodo de ciertos ámbitos poblacionales, como apuntó para el caso de los barrios de Tlatelolco o Santa María, atrayendo hacia la urbe a los indios dispersos en las periferias, lo que consolidaría no solo una "imagen” urbana, sino también el control eclesiástico de tales sectores sociales. De la misma forma, el arzobispo sorteó los argumentos socioeconómicos e históricos esgrimidos por sus opositores -como el mantenimiento de las congruas y las fábricas parroquiales en las nuevas feligresías o la tradicional dependencia de unos espacios sobre otros- y centró la discusión en la armonía, la forma o el orden de la ciudad, no viéndose afectados más que unos pocos linderos y cuestiones toponímicas, aspectos que precisamente sí se materializaban en el soporte cartográfico.

Como síntesis de ambos niveles, la imagen planimétrica se erigió como una metáfora o demostración visual de los valores 
discursivos de los informes. Desde una perspectiva espacial, junto a los argumentos textuales que acentuaron los atributos propios de una nueva urbanidad, se incorporó una capa repleta de significados alegóricos: la construcción simbólica de la ciudad como andamiaje intelectual de una necesaria intervención territorial. Así, las dimensiones temporales e ideológicas, inscritas en cada una de las proyecciones (dibujadas o textuales) que hemos analizado, nos remiten al proceso de construcción de los vectores espaciales de la reforma parroquial. Aquellos planos desplegaron un mundo de prácticas concretas tanto como de posibilidades ilustradas que, en palabras de Karl Schlögel, se convierten, ante nuestros ojos, "en boletos de entrada a espacios virtuales extintos, a libretas de notas de una búsqueda de pistas en que todo se ha perdido y no obstante algo ha quedado. Nos conducen a ciudades imaginarias, invisibles". ${ }^{202}$

\section{SIGLAS Y REFERENCIAS}

AGN, $B$ Archivo General de la Nación, fondo Bandos, Ciudad de México, México.

AGN, TC Archivo General de la Nación, fondo Templos y conventos, Ciudad de México, México.

AGN, D Archivo General de la Nación, fondo Desagüe, Ciudad de México, México.

AGN, $H$ Archivo General de la Nación, fondo Historia, Ciudad de México, México.

AGN, CV Archivo General de la Nación, fondo Correspondencia de virreyes, Ciudad de México, México.

AGN, RCO Archivo General de la Nación, fondo Reales cédulas originales, Ciudad de México, México.

AGI, $M$ Archivo General de Indias, fondo México, Sevilla, España.

AGI, $M P, M \quad$ Archivo General de Indias, fondo Mapas y Planos, sección México, Sevilla, España.

ACM, AC Archivo Histórico del Cabildo Catedral Metropolitano de México, fondo Actas de Cabildo, Ciudad de México, México.

202 Schlögel, En el espacio, p. 308. 
BCM, $B L, P V$ Biblioteca de Castilla-La Mancha, fondo Colección BorbónLorenzana, sección Papeles varios, Toledo, España.

BNF, $M M$ Bibliothèque Nationale de France, fondo Manuscrits Mexicains, París, Francia.

LC, GM Library of Congress, Geography \& Map Reading Room, Washington DC, Estados Unidos.

MN Archivo del Museo Naval, Madrid, España.

"Memoria" Alzate, José Antonio, "Memoria del plano con la nueva distribución parroquial de México", 23 de enero de 1769. BCM, $B L, P V$, ms. 26, n. 13.

"Papel” Alzate, José Antonio, "Papel sobre el arreglo de parroquias de la ciudad y arrabales de México", c. 1768. BCM, $B L, P V$, ms. 26, n. 10.

Aguirre, Rodolfo, "La secularización de doctrinas en el arzobispado de México: realidades indianas y razones políticas, 1700-1749", en Hispania Sacra, Lx: 122 (jul.-dic. 2008), pp. 487-505.

Ajofrín, Francisco de, Diario del viaje que por orden de la Sagrada Congregación de Propaganda Fide hizo a la América septentrional en el siglo XVIII, edición y prólogo de Vicente Castañeda y Alcocer, Madrid, Real Academia de la Historia, 1953, Archivo Documental Español, t. XII, vol. I.

Álvarez-Icaza Longoria, María Teresa, "La reorganización del territorio parroquial de la arquidiócesis de México durante la prelacía de Manuel Rubio y Salinas (1749-1765)", en Hispania Sacra, LXIII: 128 (jul.-dic. 2011), pp. 501-518.

Álvarez-Icaza Longoria, María Teresa, "La secularización de doctrinas de indios en la ciudad de México”, en Castro Gutiérrez (coord.), 2010, pp. 303-325.

Álvarez-Icaza Longoria, María Teresa, La secularización de doctrinas y misiones en el arzobispado de México, 1749-1789, México, Universidad Nacional Autónoma de México, 2015.

Alzate y Ramírez, José Antonio, Gacetas de literatura de México, Puebla, Manuel Buen Abad editor, 1831, t. IV.

Alzate y Ramírez, José Antonio, Memorias y ensayos, edición e introducción de Roberto Moreno de los Arcos, Universidad Nacional Autónoma de México, 1985. 
Bernabéu Albert, Salvador, Las huellas de Venus: el viaje del astrónomo Chappe d'Auteroche a Nueva España, 1768-1769, México, Breve Fondo Editorial, 1998.

Calderón de la Barca, Pedro, La piel de Gedeón, edición crítica de Ana Armendáriz, Zaragoza, Universidad de Navarra, Edition Reichenberg, 1998.

Castro Gutiérrez, Felipe (coord.), Los indios y las cindades de Nueva Espa$\tilde{n} a$, México, Universidad Nacional Autónoma de México, 2010.

Castro Gutiérrez, Felipe, "El origen y conformación de los barrios de indios”, en Gutiérrez CASTro (coord.), 2010, pp. 105-122.

Certeau, Michel de, La invención de lo cotidiano. 1 Artes de hacer, México, Universidad Iberoamericana, Instituto Tecnológico y de Estudios Superiores de Occidente, 2000.

Chappe D'Auteroche, Jean, Voyage en Californie pour l'observation du passage de Vénus sur le disque du Soleil, le 3 Juin 1769. Contenant les observations de ce phénomène, E la description historique de la route de l'Auteur à travers le Mexique. Parben M. Chappe d'Auteroche, de la Académie Royale des Sciences. Rédigé E publié par M. de Cassini fils, de la même Académie, Directeur en survivance de l'Observatoire Royal de Paris, París, Chez Charles-Antoine Jombert, 1772.

DÁvalos, Marcela, Basura e Ilustración. La limpieza de la ciudad de México a fines del siglo XVIII, México, Instituto Nacional de Antropología e Historia, Departamento del Distrito Federal, 1997.

DÁvalos, Marcela, Los letrados interpretan la ciudad: los barrios de indios en el umbral de la Independencia, México, Instituto Nacional de Antropología e Historia, 2009.

Diccionario de Autoridades, Madrid, Real Academia Española, 1726-1739, t. IV.

Escamilla González, Iván, "El arzobispo Lorenzana: la Ilustración en el IV Concilio de la Iglesia mexicana”, en Martínez López-Cano y Cervantes Bello (coords.), 2005, pp. 123-144.

Escamilla GonZÁlez, Iván, "La Iglesia y los orígenes de la Ilustración novohispana”, en Martínez López-Cano (coord.), 2010, pp. 105-127. 
Fernández Christlieb, Federico, Europa y el urbanismo neoclásico en la ciudad de México. Antecedentes y esplendores, Instituto de Geografía, Universidad Nacional Autónoma de México, 2000.

Fernández Vallina, Emiliano, "Una guirnalda de símbolos: el Libellus de Corona Virginis”, en Hinojo Andrés y Fernández Corte (eds.), 2007, pp. 337-347.

García Ayluardo, Clara (coord.), Las reformas borbónicas, 1750-1808, México, Centro de Investigación y Docencia Económicas, Fondo de Cultura Económica, Conaculta, Instituto Nacional de Estudios Históricos sobre la Revolución Mexicana, Fundación Cultural de la Ciudad de México, 2010.

García Ayluardo, Clara, "Re-formar la Iglesia novohispana”, en García Ayluardo (coord.), 2010, pp. 255-287.

García-Cubas, Antonio y Martha Reguero, Catálogo ilustrado de moluscos bivalvos del Golfo de México y Mar Caribe, México, Universidad Nacional Autónoma de México, 2007.

Gonzalbo Aizpuru, Pilar, Del barrio a la capital. Tlatelolco y la Ciudad de México en el siglo XVIII, México, El Colegio de México, 2017.

GRUZINSKI, Serge, “La 'segunda aculturación': El estado ilustrado y la religiosidad indígena en Nueva España (1775-1800)”, en Estudios de Historia Novohispana, 8 (1985), pp. 175-201.

Gutiérrez, Édgar Omar, "Juan Gassiot y su plan para poblar Arizpe. Un caso de proyectismo en Sonora”, en Estudios de Historia Novobispana, 51 (2014), pp. 75-106.

Hera, Alberto de la, "El regalismo español y su proyección en Indias en tiempos del arzobispo Lorenzana”, en Paniagua Pérez (coord.), 2005, pp. 11-20.

Hernández Franyuti, Regina (comp.), La ciudad de México en la primera mitad del siglo XIX, México, Instituto de Investigaciones Dr. José María Luis Mora, 1994, t. I.

Hernández Franyuti, Regina, "Ideología, proyectos y urbanización en la ciudad de México, 1760-1850”, en Hernández Franyuti (comp.), 1994, t. I, pp. 116-160. 
Hinojo Andrés, Gregorio y José Carlos Fernández Corte (eds.), Mvnvs Qvaesitum Meritis. Homenaje a Carmen Codoñer, Salamanca, Ediciones Universidad de Salamanca, 2007.

Lefebvre, Henri, La revolución urbana, Madrid, Alianza Editorial, 1976.

LiRA, Andrés, "Divisiones de la ciudad de México en los siglos XviII y xIx (De la ciudad de dos repúblicas a la ciudad republicana)", en Negrete SALAs, Levi y PAGE (coords.), 2003, pp. 35-58.

LiRA, Andrés, Comunidades indígenas frente a la Ciudad de México. Tenochtitlan y Tlatelolco, sus pueblos y barrios, 1812-1919, México, El Colegio de México, El Colegio de Michoacán, 1983.

Lombardo de Ruiz, Sonia, Atlas histórico de la Ciudad de México, México, Smurfit Cartón y Papel de México, Consejo Nacional para la Cultura y las Artes, Instituto Nacional de Antropología e Historia, 1996.

Lorenzana y Buitrón, Francisco Antonio de, Cartas pastorales y edictos del Illmo. Señor D. Francisco Antonio Lorenzana y Buitrón, arzobispo de México, México, Imprenta del Superior Gobierno del bachiller don Joseph Antonio de Hogal, 1770.

Maluquer de Montes, Juan y varios autores, Vivienda y urbanismo en España, Barcelona, Banco Hipotecario, 1982.

Martínez López-Cano, María del Pilar (coord.), La Iglesia en Nueva España. Problemas y perspectivas de investigación, México, Universidad Nacional Autónoma de México, 2010.

Martínez López-Cano, María del Pilar y Francisco Javier Cervantes Bello (coords.), Los concilios provinciales en Nueva España. Reflexiones e influencias, México, Universidad Nacional Autónoma de México, Benemérita Universidad Autónoma de Puebla, 2005.

Mazín, Óscar, "Espacio social y jurisdicción en los padrones del Sagrario Metropolitano de México”, en Mazín y Sánchez de Tagle (coords.), 2009, pp. 51-58.

Mazín, Óscar y Esteban Sánchez de TAgle (coords.), Los "Padrones" de confesión y comunión de la Parroquia del Sagrario Metropolitano de la Ciudad de México, México, El Colegio de México, Red Columnaria, 2009. 
Moreno de los Arcos, Roberto, "La familia y los bienes de José Antonio de Alzate”, en Real Sociedad Bascongada de los Amigos del País, 1994, t. II, pp. 647-673.

Moreno de los Arcos, Roberto, "Los territorios parroquiales de la ciudad arzobispal”, en Cuadernos de Arquitectura Virreinal, 12 (dic. 1992), pp. 4-18.

Moreno de los Arcos, Roberto, Un eclesiástico criollo ante el Estado borbón. Discurso, México, Academia Mexicana de la Historia, Universidad Nacional Autónoma de México, 1980.

Mundy, Barbara E., "Place-Names in Mexico-Tenochtitlan", en Ethnohistory, 61: 2 (2014), pp. 329-355.

Mundy, Barbara E., "The Images of Eighteenth-Century Urban Reform in Mexico City and the Plan of José Antonio Alzate", en Colonial Latin American Review, 21: 1 (abr. 2012), pp. 45-75.

MuÑoz PÉREz, José, “Los proyectos sobre España e Indias en el siglo xviII: el proyectismo como género”, en Revista de Estudios Políticos, 81 (1955), pp. 169-195.

Navarro García, Luis (ed.), Homenaje al Dr. Muro Orejón, Sevilla, Universidad de Sevilla, 1980, vol. 2.

Negrete Salas, María Eugenia, Silvana Levi y John Page (coords.), Entre fenómenos físicos y bumanos, México, El Colegio de México, 2003.

Nova Vulgata. Bibliorum Sacrorum Editio, Ciudad del Vaticano, Libreria Editrice Vaticana, 1986.

O'Gorman, Edmundo (comp.), Seis estudios históricos de tema mexicano, Xalapa, Universidad Veracruzana, 1960.

O’Gorman, Edmundo, “Reflexiones sobre la distribución urbana colonial de la ciudad de México”, en O’Gorman (comp.), 1960, pp. 11-40.

O'Hara, Matthew D., A Flock Divided. Race, Religion, and Politics in Mexico, 1749-1857, Durham, Londres, Duke University Press, 2010.

Oncina Coves, Faustino, Historia conceptual, Ilustración y modernidad, Barcelona, Anthropos, 2009. 
Orozco y Berra, Manuel, Memoria para el plano de la ciudad de México, México, Imprenta de Santiago White, 1867.

Paniagua Pérez, Jesús (coord.), España y América entre el barroco y la Ilustración (1722-1804): II centenario de la muerte del cardenal Lorenzana (1804-2004), León, España, Universidad de León, 2005.

Pescador, Juan Javier, De bautizados a fieles difuntos. Familia y mentalidades en una parroquia urbana: Santa Catarina de México: 1568-1820, México, El Colegio de México, 1992.

Pastoureau, Michel, Los colores de nuestros recuerdos, Cáceres, Periférica, 2017.

Real Sociedad Bascongada de los Amigos del País, IV Seminario de Historia de la Real Sociedad Bascongada de los Amigos del País "La R. S. B. A. P. y Méjico", México DF., septiembre de 1993, San Sebastián, Real Sociedad Bascongada de los Amigos del País, 1994, t. II.

Reguera Rodríguez, Antonio, Territorio ordenado, territorio dominado. Espacios, políticas y conflictos en la España de la Ilustración, León, España, Universidad de León, 1993.

Revillagigedo, virrey conde I de [Juan Francisco Güemes y Horcasitas], "Oficio del conde de Revillagigedo sobre secularización de curatos y separar de ellos a los regulares", 8 de octubre de 1755, en Instrucciones que los virreyes de Nueva España dejaron a sus sucesores. Añádanse algunas que los mismos trajeron de la Corte y otros documentos semejantes a las instrucciones, México, Imprenta Imperial, 1867, pp. 41-43.

Rojas Rabiela, Teresa (coord.), José Antonio Alzate y la ciencia mexicana, México, Universidad Michoacana de San Nicolás de Hidalgo, Sociedad Mexicana de Historia de la Ciencia y la Tecnología, 2000.

Romero Galván, José Rubén, “La ciudad de México, los paradigmas de dos fundaciones", en Estudios de Historia Novohispana, 20 (1999), pp. 13-32.

Rubial García, Antonio, "Civitas Dei et novus orbis. La Jerusalén celeste en la pintura de Nueva España”, en Anales del Instituto de Investigaciones Estéticas, 70 (1998), pp. 5-37.

Rubial García, Antonio (coord.), La Iglesia en el México colonial, México, Universidad Nacional Autónoma de México, Instituto de Ciencias Sociales y 
Humanidades “Alfonso Vélez Pliego", Benemérita Universidad Autónoma de Puebla, Ediciones de Educación y Cultura, 2013.

Rubial García, Antonio, “¿El final de una utopía? El arzobispo Lorenzana y la nueva distribución parroquial de la ciudad de México”, en Paniagua Pérez (coord.), 2005, pp. 277-291.

Saladino García, Alberto, El sabio José Antonio de Alzate y Ramírez de Santillana, México, Universidad Autónoma del Estado de México, 2001.

SAmbricio, Carlos, "El urbanismo de la Ilustración (1750-1814)", en MaLuQUER DE MONTES y varios autores, 1982, pp. 139-157.

SÁnChez de TAgLe, Esteban, “Antonio Alzate y la remodelación urbana del despotismo ilustrado”, en Rojas Rabiela (coord.), 2000, pp. 163-178.

SÁnchez de TAgle, Esteban, "La remodelación urbana de la ciudad de México en el siglo xviII. Una crítica de los supuestos”, en Tiempos de América, 5-6 (2000), pp. 9-19.

SÁnchez de TAgle, Esteban, Los dueños de la calle. Una historia de la vía pública en la época colonial, México, Instituto Nacional de Antropología e Historia, Departamento del Distrito Federal, 1997.

SÁnchez Santiró, Ernest, "El nuevo orden parroquial de la Ciudad de México: población, etnia y territorio (1768-1777)”, en Estudios de Historia Novohispana, 30 (2004), pp. 63-92.

SÁnchez Santiró, Ernest, Padrón del arzobispado de México 1777 (CDROM), México, Archivo General de la Nación, 2003.

SCHLÖGEL, Karl, En el espacio leemos el tiempo. Sobre historia de la civilización y geopolítica, Madrid, Ediciones Siruela, 2007.

SENNET, Richard, Carne y piedra. El cuerpo y la ciudad en la civilización occidental, Madrid, Alianza Editorial, 1997.

Sierra Nava-Lasa, Luis, El cardenal Lorenzana y la Ilustración, Madrid, Fundación Universitaria Española, 1957, t. I.

Signorelli, Amalia, Antropología urbana, Barcelona, México, Anthropos, Universidad Autónoma de México, 1999. 
TAYLOR, William B., Ministros de lo sagrado. Sacerdotes y feligreses en el México del siglo XVIII, México, El Colegio de México, Secretaría de Gobernación, El Colegio de Michoacán, 1999, vol. I.

Torquemada, Fray Juan de, Monarquia Indiana. De los veinte y un libros rituales y monarquí indiana, con el origen y guerras de los indios occidentales, de sus poblazones, descubrimiento, conquista, conversión y otras cosas maravillosas de la mesma tierra, coordinado por Miguel León-Portilla, México, Instituto de Investigaciones Históricas, Universidad Nacional Autónoma de México, 1975, vol. I.

Toussaint, Manuel, Federico Gómez de Orozco y Justino Fernández, Planos de la ciudad de México, siglos XVI y XVII. Estudio histórico, urbanístico y bibliográfico, México, Universidad Nacional Autónoma de México, Departamento del Distrito Federal, 1990.

Trabulse, Elías, Historia de la Ciencia en México. Estudios y textos. Siglo XVIII, México, Fondo de Cultura Económica, 1985.

Tuan, Yi-Fu, Space and Place: The Perspective of Experience, Minneapolis, University of Minnesota Press, 1977.

Villafañe, Justo, Introducción a la teoría de la imagen, Madrid, Ediciones Pirámide, 2006.

Villarroel, Hipólito, Enfermedades políticas que padece la capital de esta Nueva España en casi tosos los cuerpos de que se compone y remedios que se le deben aplicar para su curación si se quiere que sea útil al rey y al público, México y julio 1 de 1787, México, Gobierno de la Ciudad de México, Miguel Ángel Porrúa, 1999.

Villaseñor y Sánchez, José Antonio de, Theatro Americano. Descripción general de los reynos y provincias de la Nueva España y sus jurisdicciones. Seguido de Suplemento al Theatro Americano (La ciudad de México en 1755), edición y preliminar de Ernesto de la Torre Villar, estudio introductorio de Alejandra Espinosa Pitman, México, Universidad Nacional Autónoma de México.

Zahino Peñafort, Luisa (recopiladora), El Cardenal Lorenzana y el IV Concilio Provincial de México, México, Universidad Nacional Autónoma de México, Miguel Ángel Porrúa, Universidad de Castilla-La Mancha, 1999.

Zahino Peñafort, Luisa, Iglesia y sociedad en México, 1765-1800. Tradición, reforma y reacciones, México, Universidad Nacional Autónoma de México, 1996. 
